\title{
GRAĐANSKOPRAVNA ODGOVORNOST ZA POVREDU MEDICINSKOG STANDARDA I PRATEĆI EKONOMSKI UČINCI
}

Dr. sc. Hrvoje Vojković*

\author{
UDK: 347.426 \\ https://doi.org/10.30925/zpfsr.40.2.3 \\ Ur.: 3. travnja 2019. \\ Pr.: 28. lipnja 2019. \\ Izvorni znanstveni rad
}

\begin{abstract}
Sažetak
U radu je analiziran građanskopravni aspekt povrede medicinskog standarda tijekom pružanja usluge medicinskog postupanja te se ukazalo na različite pojavne oblike liječničke pogreške. Uobičajeni je modus povrede medicinskog standarda liječnička pogreška, koja se neovisno o tipološkim značajkama očituje, in genere, u postupanju liječnika, protivno pravilima zdravstvene struke te njenim moralnim i etičkim načelima, odnosno kao postupanje u neskladu s provjerenim standardima suvremene medicinske znanosti. U okviru provedenog istraživanja utvrđen je conceptum pravno relevantnoga medicinskog standarda na temelju imaginarnog modela ponašanja liječnika u okviru medicinskoga tretmana in concreto. Pritom se kao relevantan pravni standard uzima pažnja dobroga gospodarstvenika i dobroga stručnjaka, a njegovo pridržavanje smanjuje rizik od suboptimalnog tretmana koji bi bio suprotan pravilima medicinske profesije - contra legis artis. Primjena pravila dužne pažnje, odnosno, odštetnopravni sustav sa svojim pravnim i ekonomskim implikacijama, in ultima linea, dovodi do toga da mogući štetnik (liječnik/zdravstvena ustanova) medicinsku uslugu nastoji obavljati u režimu standarda optimalne skrbi, budući da pravni sustav navedeni standard medicinskog postupanja izjednačuje s ekonomskom kategorijom optimalne skrbi za pacijenta.
\end{abstract}

Ključne riječi: građanskopravna odgovornost liječnika; dužna pažnja liječnika; pažnja dobroga gospodarstvenika; povreda standarda medicinskog tretmana; liječnička pogreška; ekonomika zdravstvenih ustanova.

* Dr. sc. Hrvoje Vojković, Gras Savoye Croatia d.d., Willis Towers Watson group, hvojkovic@ gmail.com 


\section{PRAVNI OGLED NA FENOMENOLOGIJU LIJEČNIČKIH POGRES̆KI S PRATEĆIM EKONOMSKIM UČINCIMA}

Primjena građanskopravnog standarda dužne pažnje liječnika, a napose u korelaciji sa pratećim ekonomskih učincima, postala je s vremenom sve intrigantnija tema, a povećanje interesa u javnosti može se pripisati prelijevanju vanjskih trendova. Uvodno valja ustvrditi da medicina nije statična znanost te da medicinsko postupanje nije moguće potpuno standardizirati s obzirom na permanentni znanstveni napredak koji uvjetuje određene modifikacije dijagnostičkih i terapijskih postupaka. Sukladno inherentnom dinamizmu medicinske znanosti, isprva valja konstatirati da pružanje zdravstvene usluge nosi određeni rizik koji može rezultirati u ozbiljenju neželjenih posljedica medicinskog tretmana s obilježjima liječničke pogreške ili pak povrede prava na suodlučivanje (informirani pristanak). U dijelu pravne znanosti ukazuje se na fenomen denuncijacije i/ili parničenja kad se smatra da postoji odstupanje od zahtijevanog medicinskog standarda ${ }^{1}$ te se navodi podatak da je u proteklom desetljeću zabilježen porast od preko 50 \%. Tako prema Specijalnom Eurobarometru o medicinskim pogreškama oko $80 \%$ građana EU-a percipira medicinske pogreške kao glavno pitanje, a oko $50 \%$ smatra da će biti osobno oštećeni zbog povrede medicinskog standarda. Indikativan je podatak da su posljedice liječničkih pogreški osmi uzrok smrti u SAD-u. Nešto starije, ali uvijek ilustrativno istraživanje u dvije zdravstvene ustanove u SAD-u (1999.), pokazalo je da čak 2,9 \%, odnosno 3,9 \% bolesnika trpi povredu zdravlja što je u kauzalnoj vezi sa provedenim medicinskim tretmanom, dok u Danskoj taj postotak iznosi visokih 9 \%, u Francuskoj 8,9 \%, a u Velikoj Britaniji $11 \%$. $^{2}$ Međunarodna literatura upućuje na trend "povećanja sklonosti traženja odštete", a pacijenti sve češće izražavaju prigovore na rad liječnika te se otkrivaju ozbiljne povrede pravila medicinske struke koje su trebale biti unutarnjim kontrolama ranije uočene i otklonjene, ali ne upućuju nužno i na nisko povjerenje pacijenata u liječnike. ${ }^{3}$ Pravna i ekonomska književnost govore o pravoj ,industriji liječničke odgovornosti“" koja u SAD-u producira kumulativni godišnji izdatak po različitim osnovama od 17 do 29 USD milijardi godišnje, prema izvješću američkoga Institute of Medicine. Ističe se podatak da su posljedice liječničkih pogreški u SAD-u pretekle štete izazvane prometnim nezgodama te godišnje oštećuju više od 1,5 milijuna američkih pacijenata. ${ }^{4}$ Istovjetni se trendovi zamjećuju u Velikoj Britaniji koja bilježi znatan kontinuirani porast odštetnopravnih postupaka kojih je 1978. godine bilo tek

1 Ferrara, S. D., Boscolo-Berto., R., Viel, G. (ur.), Malpractice and Medical Liability, Berlin/ Heidelberg, Springer, 2013., str. 5.

2 Prema Škavić, J., Zečević, D., Komplikacija i greška - sudskomedicinski pristup, u: Građanskopravna odgovornost u medicini: okrugli stol održan 27. 2. 2008. u HAZU (ur. Barbić, J.), Zagreb, HAZU, 2008., str. 23.

3 Budak, J., Ocjena pacijenata o kvaliteti rada zdravstvenog osoblja, u: Vehovec, M. (ur.), O zdravstvu iz ekonomske perspektive, Zagreb, Ekonomski Institut, 2014., str. 275-276.

4 Arlen, J., Economic Analysis of Medical Malpractice Liability and its Reform, New York University Public Law and Legal Theory Working Papers. Paper 398, 2013, str. 59, <http:// citeseerx.ist.psu.edu/viewdoc/download?doi=10.1.1.828.1313\&rep=rep1\&type=pdf $>$, ožujka 2019.; Arlen, J., Contracting over Liability: Medical Malpractice and the Cost of Choice, Philadelphia, University of Pennsylvania Law Review, vol. 158, 4/2010, str. 957-1023. 
otprilike 500 u odnosu na čak 7000 od 1990. do 1991. s daljnjim eksponencijalnim trendovima u današnje vrijeme. ${ }^{5}$ Slična je situacija i u Italiji te se izvještava o 50 \% povećanju broja parnica radi popravljanja štete zbog liječničke pogreške u vremenu od 1980. do 1986. s evidentiranim dodatnim porastom od $90 \%$ u $1987 .{ }^{6} \mathrm{U}$ Italiji se na godišnjoj razini pokreće otprilike 15.000 odštetnopravnih postupaka zbog šteta prouzročenih liječničkom pogreškom, a zdravstvene ustanove na ime odštete pacijentima isplaćuju ukupni iznos od čak oko 10 milijardi eura. ${ }^{7}$

Nasuprot opisanoj situaciji, u Hrvatskoj fenomenologija liječničkih pogreški još uvijek nije kolektivno legitimirana kao važna tema u krugu pravnei ekonomske znanosti. Hrvatsku znanstvenu stvarnost karakterizira nedostatak relevantnih istraživanja, dok se javnost tek sporadično bavi nekim drastičnim slučajevima liječničkih pogreški (npr. Maškarin) s natruhama "senzacionalizma", a što sve upućuje na opću imperfektnost pravno-ekonomskog mehanizma zaštite prava pacijenata zbog povrede standarda medicinskoga tretmana. Međutim, slabe strane modela pravne zaštite ipak se ne bi mogle pripisati niti pravnoj insuficijenciji niti inerciji pravosudnog sustava, već prije određenim nediferenciranim nepravnim i neekonomskim čimbenicima uvjetovanim kolektivnom psihologijom i sustavom vrijednosti, u okolnostima kada liječnička profesija još uvijek uživa visoki stupanj javnog odobravanja i poštovanja. Neovisno o tome treba napomenuti da pozitivno pravo RH explicite normira načelo učinkovitosti $i$ djelotvornosti sustava kvalitete zdravstvene zaštite i sigurnosti zdravstvenih postupaka te prihvaća sintagmu kvalitete zdravstvene zaštite koja neizravno utječe na oblikovanje konstrukcije medicinskog standarda in praxi. Načelno, medicinski standard u pružanju zdravstvene usluge zasniva se na općoj obvezi liječnika da tijekom medicinskog tretmana poštuje odgovarajući medicinski protokol te da primijeni standard dužne pozornosti koja odgovara njegovoj profesiji i dodatnoj specijalizaciji.

Razmatrajući građanskopravni aspekt povrede medicinskog tretmana potrebno je naglasiti da se u hrvatskom pravu i pravnim poredcima ad comparandum pitanje liječničke pogreške prosuđuje u kontekstu konkretnog dijagnostičko-terapijskog postupka koji je oridiniran. Pritom mjerilo ponašanja nije prosječno pametna i pažljiva osoba, nego uobičajeno pažljiv doktor. Proizlazi da zahtijevani prosječni standard nije prosječni standard građanina, već prosječni standard koji vrijedi za liječnike - bonus pater familias standard ${ }^{8}$ koji odgovara pažnji dobrog stručnjaka (gospodarstvenika) $\mathrm{u}$ hrvatskom pravu. Utvrditi pravno relevantan sadržaj standarda medicinske struke znači da nije dostatno samo utvrditi ustaljena i priznata pravila medicinske profesije, već treba ocijeniti postupanje liječnika u konkretnim okolnostima. Slijedom toga, jedini „zajednički nazivnik“ za utvrđivanje postojanja pogreške u medicinskom tretmanu

5 Tarantino, U. i dr., Profesional Liability in Orthopaedics and Traumatology in Italy, Philadelphia, Clinical Orthopaedics and Related Research, vol. 471, 10/2013., str. 6.

6 Traina, F., Medical Malpractice: Experience in Italy, Philadelphia, Clinical Orthopaedics and Related Research, vol. 467, 2/2009, str. 1-13.

7 ibid., str. 1.

8 Faure, M. G., Economic observations concerning optimal prevention and compensation of damage caused by medical malpractice, u: Dute, J., Faure, M. G., Koziol, H. (ur.), No-fault compensation in the health care sector, Wien/New York, Springer, 2004., str. 19. 
može biti povreda dužne pažnje, ${ }^{9}$ koja indicira postojanje krivnje kao subjektivnog elementa protupravnosti i pretpostavke građanskopravne odgovornosti.

Središnje istraživačko pitanje ovog rada odnosi se na analizu građanskopravnog aspekta povrede medicinskog standarda koji nastaje tijekom pružanja usluge medicinskog tretmana s diferentnim pojavnim oblicima liječničke pogreške. U okviru provedene analize utvrđen je conceptum pravno relevantnog medicinskog standarda $\mathrm{i}$ to na temelju imaginarnog modela ponašanja liječnika u okviru medicinskog tretmana in conreto, pri čemu je mjerilo ponašanja uobičajeno pažljiv liječnik određene specijalizacije. U ostvarenju cilja rada istraženi su konstitutivni elementi građanskopravne konstrukcije odgovornosti zbog medicinskog standarda liječnika s posebnim osvrtom na pretpostavke građanskopravne odgovornosti. Nastavno su analizirani ekonomski učinci primjene instituta građanskopravne odgovornosti zbog povrede medicinskoga standarda (liječnička pogreška), a napose financijski aspekt u svom totalitetu (trošak odštete, medicinske prevencije, ukupni društveni trošak) te su izloženi referentni ekonomski modeli usmjereni na uspostavu optimalnog standarda zdravstvene skrbi.

Prema strukuri rada, uvodno se osvrće na fenomenologiju liječničkih pogreški in contextu širega pravnog, sociološkog i ekonomskog okvira pružanja zdravstvene usluge u inačici ars medica, kao i contra lege artis s posljedicom građanskopravne odgovornosti za štetu zbog liječničke pogreške. Nastavno je izložen presjek strukture tipičnog odštetnopravnog postupka za naknadu štete zbog liječničke pogreške $s$ primjerima iz hrvatske i komparativne prakse koji su prikazani po kriteriju tipologije liječničkih pogreški. Zaključno su istraženi ekonomski učinci primjene instituta građanskopravne odgovornosti zbog povrede medicinskog standarda te je inter alia ekspliciran temeljni ekonomski model usmjeren na ekonomski učinkovito pružanje zdravstvene usluge. Sukladno tomu analizirani su zajednički kohezivni elementi korelativnih pravnih instituta i komplementarne ekonomike te njihova interakcija, čime se posredno i na načelu uzajamnosti stvaraju odgovarajuće pravno-ekonomske posljedice. metoda.

U radu su primijenjene komparativna i induktivna znanstvenoistraživačka

\section{GRAĐANSKOPRAVNI CONCEPTUM PROFESIONALNOG STANDARDA POSTUPANJA LIJEČNIKA}

\subsection{Općenito}

Uvodno valja napomenuti da medicinsku i pravnu morfologiju medicinskog standarda u Hrvatskoj određuje načelo sigurnosti pacijenata koje se ostvaruje provedbom mjera kojima se svakom pacijentu osigurava pravo na kvalitetnu zdravstvenu zaštitu sukladno njegovu zdravstvenom stanju i općeprihvaćenim stručnim standardima te kojima se sprječavaju štetni neželjeni događaji, čija bi

9 Petrić, S., Građanskopravna odgovornost zdravstvenih djelatnika, Rijeka, Zbornik Pravnog fakulteta Sveučilišta u Rijeci, vol. 26, 1/2005, str. 123. 
posljedica mogla biti smrt ili oštećenje zdravlja pacijenta. Provedbom navedenih mjera treba ostvariti podizanje svijesti o sigurnosti pacijenata, razvoj i unaprjeđenje sustava praćenja i mjerenja sigurnosti pacijenata, kao i izvješćivanja na tom području, smanjenju rizika za neželjene događaje te razvoj istraživanja na području sigurnosti pacijenata. ${ }^{10}$ Normirajući problematiku kvalitete zdravstvene zaštite, utvrđeno je načelo učinkovitosti i djelotvornosti sustava kvalitete zdravstvene zaštite i sigurnosti zdravstvenih postupaka, koje se ostvaruje provedbom mjera za osiguranje kvalitete zdravstvene zaštite. Time se postiže optimalni odnos između učinaka provedenih zdravstvenih postupaka i troškova nastalih njihovom provedbom, pritom uvažavajući tehničke, organizacijske i gospodarske čimbenike. ${ }^{11}$ Standardi kvalitete zdravstvene zaštite jesu precizni kvantificirani opisi mjerila u vezi s obavljanjem zdravstvenih postupaka, zdravstvenim radnicima, opremom, materijalima i okolišem u kojim se obavljaju zdravstveni postupci, a kojima se osigurava kvaliteta zdravstvene zaštite. Radi osiguranja učinkovite, djelotvorne, jednako visokokvalitetne i jednako dostupne zdravstvene zaštite u svim zdravstvenim djelatnostima, na svim razinama zdravstvene zaštite te na cijelom području Republike Hrvatske, ministar nadležan za zdravstvo na prijedlog Agencije za kvalitetu i akreditaciju u zdravstvu, po prethodno pribavljenom mišljenju nadležnih komora, donosi plan i program mjera za osiguranje, unaprjeđenje, promicanje i praćenje kvalitete zdravstvene zaštite, kojim se utvrđuju se prioriteti za poboljšanje kvalitete zdravstvene zaštite te mjere za uvođenje jedinstvenog sustava standarda kvalitete zdravstvene zaštite i kliničkih pokazatelja kvalitete. Navedene mjere obvezatni su provoditi svi nositelji zdravstvene djelatnosti radi uspostave hrvatskoga standarda kvalitete zdravstvene zaštite i procjene sigurnosti pacijenata. ${ }^{12}$

Obavljanje usluge medicinskog tretmana počiva na zahtjevu da liječnik u svakom pojedinačnom slučaju mora slijediti medicinski protokol, kao i primijeniti zahtijevani standard dužne pozornosti koja odgovara njegovoj struci. Medicinski standard jedinstveno se primjenjuje u svojoj punini uz neke iznimke koje, u pravilu, proizlaze iz žurnosti provođenja zdravstvenoga zahvata.

\subsection{Medicinski standard pružanja usluge liječničkog tretmana}

In generali sensu, medicinski standard pretpostavlja primjenu općenitih jednoznačnih pravila kojih se mora pridržavati svaki liječnik, ali istodobno u medicinski standard spadaju i svi drugi postupci liječnika koji su rezultat novijih znanstvenomedicinskih spoznaja i primjenjuju se u širem krugu liječničke profesionalne zajednice. ${ }^{13}$ Liječnik mora biti posjednik stručnog znanja i kompetencije kako bi jamčio provođenje medicinskog tretmana sukladno pravilima medicinske profesije koje se zasnivaju na stručnom standardu postupanja iskusnog liječnika u okviru

10 Čl. 5. Zakona o kvaliteti zdravstvene zaštite, NN, br. 118/18.

11 Čl. 4. Zakona o kvaliteti zdravstvene zaštite, NN, br. 118/18.

12 Čl. 6. Zakona o kvaliteti zdravstvene zaštite, NN, br. 118/18.

13 Kullmann, H. J., Übereinstimmungen und Unterschiede im medizinischen, haftungsrechtlichen und sozialversicherungsrechtlichen Begriff des medizinischen Standards, Versicherungsrecht, 13/1997, str. 529. 
odgovarajuće medicinske specijalizacije. ${ }^{14}$

Nužno je naglasiti kako medicinsko postupanje nije moguće potpuno standardizirati s obzirom na permanentni znanstveni napredak koji uvjetuje određene modifikacije dijagnostičkih i terapijskih postupaka. Tako citirani Zakon o zdravstvenoj zaštiti uzima u obzir promjenjivu kategoriju profesionalnog medicinskog standarda i utvrđuje pravo i obvezu zdravstvenih djelatnika da se stručno usavršavaju radi održavanja i unapređivanja kvalitete zdravstvene zaštite. ${ }^{15}$ Pravna književnost upozorava da je liječnik obvezan pružiti zdravstvenu uslugu tek nakon što je prethodno razmotrio sve okolnosti medicinskog slučaja i uzeo u obzir sve povoljne i nepovoljne momente koji se tiču dijagnoze ili planiranoga medicinskog tretmana. ${ }^{16}$ Prema tomu, od liječnika se očekuje da u pogledu primijenjene metode liječenja u pojedinom slučaju izabere onu koja ponajviše smanjuje rizik od nastupa medicinske komplikacije, odnosno da prihvati metodu koja u cijelosti isključuje mogućnost nastupa štetne posljedice za zdravlje pacijenta u okviru poduzetoga medicinskog tretmana. Dijagnostičko-terapijski postupak koji je usklađen sa zahtijevanim medicinskim standardom $\mathrm{u}$ pojedinoj oblasti medicine isključuje eventualnu građanskopravnu odgovornost, čak i u situaciji kada kao posljedica liječničke intervencije nastupe izvjesne komplikacije koje su u korelaciji s uobičajenim rizikom poduzimanja odnosnog medicinskog zahvata. ${ }^{17}$

Liječnik kao stručnjak ima pravo na slobodu izbora odgovarajuće terapije u smislu da samostalno odlučuje je li liječenje uopće potrebno; ne smije biti prisiljen aplicirati lijekove ili metode koje proturječe njegovoj savjesti i slobodan je u izboru dijagnostičko-terapijskih mjera koje smatra najsvrsishodnijim. Pritom se od liječnika ne zahtijeva izbor najsigurnijega terapeutskog puta, već bit odgovornog izbora valja tražiti u savjesnom odmjeravanju načela koristi i rizika. ${ }^{18} \mathrm{U}$ dijelu pravne teorije naglašava se kako medicinska praksa mora biti razumna s obzirom na okolnosti slučaja. Pritom postojanje nerazumnih medicinskih praksi, bez obzira na mogućnost da se radi o postupcima koji su s obzirom na vrijeme i mjesto općeprihvaćeni, neće osloboditi liječnika od odgovornosti. ${ }^{19}$

\subsection{Pravni standard dužne pažnje liječnika}

\subsubsection{Pravna konstrukcija standarda dužne pažnje liječnika}

Hrvatsko pravo obvezuje liječnika da postupa s povećanom pažnjom, prema

14 Ferrara, S. D., Boscolo-Berto, R., Viel, G., op. cit., str. 76-77.

15 Čl. 138. Zakona o zdravstvenoj zaštiti, NN, br. 150/2008, 155/2009, 71/2010, 139/2010, 22/2011，84/2011，154/2011，12/2012，35/2012，70/2012，144/2012，82/2013，159/2013, 22/2014, 154/2014, 70/2016, 131/2017.

16 Giesen, D., International medical malpractice law: a comparative law study of civil liability arising from medical care, Tübingen/Dordrecht/Boston/London, Mohr/Nijhoff, 1988.

17 VSRH, Rev-6/02-2 od 3. srpnja 2003.

18 Laufs, A., Uhlenbruck, W., Handbuch des Arztrechts, 3. Auflage, München, Beck, 2002., str. 18-19.

19 Giesen, op. cit., str. 120. 
pravilima struke i običajima - pažnja dobrog stručnjaka. ${ }^{20}$ Pažnja dobrog stručnjaka određuje se objektivno prema kriteriju pažnje koja se može očekivati od iskusnog i savjesnog medicinara istog ranga (njemačko pravo), odnosno dobrog stručnjaka iste kategorije i istog ranga kao i onoga čije se profesionalno postupanje ocjenjuje (liječnika opće prakse, specijalist i dr., u francuskom pravu) ili reasonably competent doctor (englesko pravo). ${ }^{21} \mathrm{U}$ istom značenju neki pravni poredci upotrebljavaju sintagmu bonus pater familias (Italija, Francuska i Španjolska), dok drugi (Velika Britanija i Skandinavske zemlje), koriste termin razuman liječnički standard u svezi s prihvaćenim pravilima medicinskog umijeća - ars medica. ${ }^{22}$ Razvidno je da utvrđenje kriterija dužne pažnje liječnika uzima u obzir i odnos iskazanog stupnja profesionalne pažnje u odnosu na osobe istog profesionalnog kruga i specifične okolnosti konkretnoga medicinskog slučaja. Ipak, opisani standard pažnje ne bi trebalo shvatiti kao kruto pravilo koje ne trpi odstupanja u praksi već bi se trebalo prilagođavati okolnostima konkretnoga medicinskog slučaja bilo u smislu ublažavanja ili pooštrenja standarda dužne pažnje. ${ }^{23}$ Dakle, standard dužne pažnje liječnika koji se zahtijeva pri obavljanju medicinskoga tretmana nad pacijentom mjeri se prema vanjskom, objektivnom standardu, a koji odgovara postupanju liječnika prosječne vještine koji u obavljanju svoje dužnosti iskazuje potrebna posebna stručna znanja. Pritom je sasvim nebitno što je zbog nedostatka sposobnosti, znanja ili iskustva, nesposoban postići zahtijevani standard postupanja, budući da liječnik treba priznati vlastita ograničenja koja se tiču njegove stručne kvalifikacije i iskustva i tamo gdje je to primjereno mora prihvatiti savjet, pomoć, uputu ili nadzor iskusnijega kolege liječnika ili uputiti pacijenta kolegi specijalistu ili u specijalističku kliniku. ${ }^{24}$

Valja uočiti da veća opasnost i veći rizik zahvata zahtijevaju veću pažnju, a hitnost i nužnost zahvata opravdavaju niži standard pažnje. ${ }^{25}$ Pritom se niži standard pažnje ne može opravdati praksom koja može biti i dosta raširena ako se radi o neurednom i površnom postupanju odnosno poslovanju. ${ }^{26}$ Uvijek se valja pitati kako bi se iskusan i pažljiv liječnik opće prakse ili specijalista ponašao u određenoj situaciji. ${ }^{27}$ Općenito, specifične okolnosti konkretnoga zdravstvenog slučaja određuju stupanj i opseg medicinskog nadzora. U svakom slučaju, kako navodi pravna teorija, liječnik u svom profesionalnom radu mora ispoljiti povećanu pažnju koja osigurava kvalitetu njegove usluge. ${ }^{28} \mathrm{Kad}$ su u pitanju izvjesne varijacije unutar medicinskog

20 Čl. 18. st. 2. Zakona o obveznim odnosima (dalje: ZOO), NN br. 35/2005, 41/2008, 125/2011, 78/2015, 29/2018.

21 Bevanda, M., Ugovor između liječnika i pacijenta, Zbornik Pravnog fakulteta Sveučilišta u Rijeci, vol. 26, 1/2005, str. 331.

22 Ferrara, S. D., Boscolo-Berto., R., Viel, G. (ur.), op. cit., str. 77.

23 Klarić, P., Odgovornost zdravstvene ustanove i zdravstvenih djelatnika za štetu, Hrvatska pravna revija, vol. 1, 8/2001, str. 74 .

24 Koziol, H., Österreichisches Haftpflichtrecht, Band II, Besonder Teil, Wien, Jan Sramek Verlag, 1984., str. 94.

25 Deutsch, E., Medizinrecht, 4. Aufl., Berlin, Springer, 1999., str. 124.

26 ibid., str. 123.

27 ibid., str. 124.

28 Radišić, J., Odgovornost zbog štete izazvane lekarskom greškom u lečenju i u obaveštavanju pacijenta, Beograd, Nomos, 2007., str. 81. 
standarda koji vrijede za liječnika opće prakse i liječnika specijaliste, načelno se zahtijeva postupanje koje odgovara prosječno stručnom liječniku, odnosno, prosječnom specijalistu ili ekspertu za pojedino medicinsko područje. U teoriji se zauzima gledište da je liječnik prihvaćanjem provođenja medicinskog tretmana nad pacijentom implicitno zajamčio da posjeduje odgovarajuće stručno znanje koje mu omogućuje provođenje zahvata nad pacijentom s dužnom pažnjom i stručnošću. To, dakako, uključuje ispravnu i stručnu procjenu vezanu za mogućnost upućivanja liječniku specijalistu ili čak drugom specijalisti radi drugoga liječničkog mišljenja.

Zaključno treba istaknuti da je liječnik dužan postupati s pažnjom koja se traži za osobe koje pripadaju istom profesionalnom krugu, odnosno s pažnjom dobrog stručnjaka, a ne tek prosječnoga stručnjaka. Kako se zdravstvena djelatnost u Republici Hrvatskoj ostvaruje u različitim organizacijskim formama (zdravstvene ustanove, trgovačka društva koja obavljaju zdravstvenu djelatnost, privatni zdravstveni radnici), kao relevantni pravni standard mogla bi se primijeniti i pažnja dobrog gospodarstvenika i dobrog stručnjaka. ${ }^{29} \mathrm{U}$ tom kontekstu nužno je naglasiti da je prevladavajuće gledište hrvatske pravne teorije kako se u pogledu obavljanja medicinskih tretmana navedeni pravni standardi sadržajno ne razlikuju, tj. da međusobno ne konkuriraju. Drugim riječima, pažnja pružatelja zdravstvenih usluga i zdravstvenih radnika koji su zaposleni kod njih trebala bi se procjenjivati s obzirom na jedan standard, unutar kojeg valja razlikovati pažnju određene specijalizacije. ${ }^{30}$ Tako se u dijelu europske pravne teorije ističe kako je liječnik obvezan zdravstvenu uslugu pružiti s povećanom pažnjom, odnosno postupati s onim stupnjem pažnje koji se redovito očekuje od dobroga stručnjaka ili gospodarstvenika u istovrsnim situacijama. Pritom se ne može opravdati time što je postupao prema svom najboljem znanju, ako se utvrdi da je to znanje za obavljanje njegovog zanimanja bilo objektivno nedostatno. ${ }^{31}$

\subsubsection{Derivacije pravnoga standarda dužne pažnje liječnika u hrvatskoj $i$ poredbenoj praksi}

U okviru prakse hrvatskih sudova, pitanje građanskopravno relevantne povrede medicinskog standarda ocjenjuje se u relaciji sa zahtijevanim stupnjem dužne pažnje liječnika in concreto, tj. procjenjuje se je li liječnik postupao s pažnjom dobrog stručnjaka. Pritom se navedeno mjerilo dovodi u vezu sa zakonskim pojmovima kvaliteta zdravstvene zaštite i standardi kvalitete zdravstvene zaštite. ${ }^{32}$ Usprkos činjenici da je profesionalni standard dužne pažnje liječnika objektivna kategorija, uvijek je valja razmatrati s obzirom na specifične okolnosti obavljanja konkretnoga medicinskog tretmana. Pri uobičajenim okolnostima obavljanje medicinskog tretmana, liječnik je obvezan uzeti u obzir sve medicinske rizike koje je razumno moguće predvidjeti. Dakle, liječnik će biti nepažljiv ako nije uzeo u obzir vlastite stručna ograničenja te je poduzeo ili nastavio liječenje umjesto da se obratio za savjet

29 Čl. 10. st. 1. i 2. ZOO-a.

30 Nikšić, S., Ugovor o zdravstvenoj usluzi, doktorska disertacija, Zagreb, Pravni fakultet, 2007. str. 438, 284.

31 Koziol, H., op. cit., str. 183.

32 Čl. 3. Zakona o kvaliteti zdravstvene zaštite. 
drugom liječniku ili je pacijenta uputio specijalisti, na bolničko liječenje ili u drugu zdravstvenu ustanovu koja ima kvalificiranije liječnike ili je opremljena boljom medicinskom tehnikom. ${ }^{33} \mathrm{U}$ tom smislu, poredbeno pravo upućuje na karakterističan slučaj iz engleske sudske prakse koji je oblikovao stajalište kako se u svakom pojedinom slučaju mora dokazati da je štetna posljedica koju trpi pacijent dio upravo onoga rizika od kojega ga je liječnik bio dužan zaštititi. Ako se utvrdi da tomu nije tako, povreda nije bitna i nije povreda dužne pažnje. Naime, od liječnika se očekuje da prevenira narušavanje pacijentova zdravlja štiteći ga od rizika koje bi sposoban liječnik predvidio kao posljedicu u slučaju postupanja bez odgovarajućega stupnja pažnje. ${ }^{34} \mathrm{~S}$ druge strane, u situaciji kada se medicinski tretman provodi u posebnim uvjetima koji objektivno onemogućuju anticipaciju svih realnih zdravstvenih rizika koji bi u uobičajenim okolnostima bili predvidljivi, medicinsko postupanje liječnika ne rezultira liječničkom pogreškom.

Od liječnika se očekuje da obavljanje zdravstvene usluge temelji na najnovijoj medicinskoj praksi jer će u suprotnom biti građanskopravno odgovoran za eventualnu štetu. Naime, liječnik ne smije propustiti primijeniti već općeprihvaćenu novu medicinsku metodu koja je obećavala veći uspjeh zdravstvenog zahvata na stanje pacijentova zdravlja, a u odnosu na stariju zdravstvenu metodu koju je u konkretnom slučaju primijenio. U sudskoj se praksi navodi slučaj ${ }^{35}$ liječnika koji je prakticirao homeopatiju te je istodobno obeshrabrio pacijenta da obavi pregled rendgenom koji je preporučio liječnik specijalist čime je ostvario povredu medicinskog stnadarda. Slično tomu praksa bilježi slučaj ${ }^{36}$ nestručnog tretmana liječnika koji je pacijenta tretirao starijim lijekom što je posljedično prouzročilo trovanje arsenom neovisno o tome što je $\mathrm{u}$ vrijeme poduzimanja tretmana primjena penicilina kao lijeka koji ne izaziva prateće negativne posljedice na zdravlje bila općeprihvaćena za takve slučajeve. Liječnik će postupiti sukladno zahtijevanom standardu dužne pažnje ako je u izboru dviju ili više prihvaćenih dijagnostičko-terapijskih metoda u pogledu istovrsnoga zdravstvenog stanja pacijenta, u konkretnom slučaju primijenio bilo koju od tih metoda i pružio

33 Radišić, J., op. cit., str. 81.

34 Brown v. Lewisham and North Southwark Health Authority MLC 0081 (CA: 1999), Medical negligence, dostupno na: http://www.medneg.com/Case/CaseList.aspx (pristupljeno 8. veljače 2013.). „Za svrhe analize ponekad je važno biti precizniji u definiciji dužne pažnje. Liječnik je obvezan postupiti s pažnjom i vještinom sposobnog liječnika. Mora postupati s dužnom pažnjom pri pregledu, postavljanju dijagnoze i liječenju pacijenta, te spriječiti narušavanje njegova zdravlja štiteći ga od rizika koje bi sposoban liječnik predvidio kao posljedicu u slučaju postupanja bez odgovarajućeg stupnja pažnje. On nije vidovit ni ako kaže pacijentu da ne može naći nikakve znakove bolesti niti može biti odgovoran ako pacijent boluje od nečega što nije bilo moguće otkriti savjesno obavljenim pregledom. Javna politika ograničavanja odgovornosti počinitelja štete kontrolnim mehanizmom predvidljivosti čini se nužnom u medicinskopravnim slučajevima, kao i u drugim područjima odštetne odgovornosti. Ne vidi se na kojoj bi to političkoj osnovi bilo pravedno ili pravično držati liječnika odgovornim za povredu dužne pažnje u slučaju propuštanja dijagnosticiranja asimptomatične i neuočljive bolesti, samo zato što je kriv za pogrešno postupanje točno dijagnosticiranog, no nepovezanog stanja. Ukratko, mora se dokazati da je štetna posljedica nastala pacijentu dio rizika od kojeg ga je liječnik bio dužan zaštititi. Ako to nije, povreda nije bitna i ne predstavlja povredu dužne pažnje.“

35 Francuski kasacijski sud (Cour de Cassation), Cass civ 1re, od 4. studenog 1964.

36 Savezni Vrhovni sud Njemačke (BGH), presuda od 16. svibnja 1972., VersR 1972. 
odgovarajuću zdravstvenu uslugu. ${ }^{37}$ Tako neće postojati liječnička pogreška kad se štetna posljedica nije mogla svladati usprkos tomu što se postupalo s potrebnom pažnjom u skladu s medicinskim standardom, a to je u konkretnom slučaju izostalo. ${ }^{38}$ Okolnost što malformacije djeteta liječnik nije otkrio ultrazvučnim pregledima nisu imale za posljedicu njegovu odgovornost za naknadu štete u konkretnom slučaju. ${ }^{39}$

\section{GRADANSKOPRAVNA ODGOVORNOST ZA POVREDU MEDICINSKOG STANDARDA I POPRAVLJANJE ŠTETE}

\subsection{Pretpostavke građanskopravne odgovornosti za štetu prouzročenu povredom medicinskog standarda (liječnička pogreška)}

Obveznopravni odnos odgovornosti za štetu nastaje tek kad se kumulativno ispune zakonom utvrđene pretpostavke, od kojih su neke zajedničke za sve vrste odgovornosti (opće pretpostavke), a druge se vezuju za pojedine vrste odgovornosti (posebne pretpostavke). Općenito, građanskopravna odgovornost za štetu nastaje kada su ispunjeni sljedeći condicio iuris: da je osoba odgovorna za štetu (štetnik) počinila protupravnu štetnu radnju zbog koje je nastala šteta osobi koja traži popravak štete (oštećenik) te da postoji kauzalni neksus između štetne radnje i štete kao posljedice. Prema tome, opće pretpostavke odštetne odgovornosti koje moraju biti ostvarene in cumulo su: a) postojanje subjekata odgovornosti; b) štetna radnja štetnika; c) šteta; d) uzročna veze između štetne radnje i štete i e) protupravnost u objektivnom smislu.

Utvrđivanje liječničke pogreške razmatra se kroz prizmu ponašanja liječnika u okviru medicinskog tretmana in concreto pri čemu mjerilo ponašanja neće biti neka prosječno pametna i pažljiva osoba, nego uobičajeno pažljiv doktor sukladno prosječnom standardu koji vrijedi za liječnike - bonus pater familias standard. ${ }^{40}$ Conditio sine qua non nastanka građanskopravne odgovornosti za štetu sastoji se na utvrđenje suda da je u određenom slučaju štetnik ostvario povredu dužne pažnje, jer nije postupao u svojstvu dobrog stručnjaka ili gospodarstvenika, a koja povreda

37 Nikšić, S., op. cit., str. 439.

38 VSRH, Rev 876/06-2 od 10.01.2007.

39 VSRH, 1808/00-2, od 15. listopada 2003.,Zaključivši da je tuženik u izvršavanju obveza iz svoje profesionalne djelatnosti u odnosu na praćenje i kontrolu trudnoće prvotužiteljice kao pacijentice u njegovoj privatnoj ginekološkoj ambulanti postupao savjesno i u skladu s pravilima struke, sukladno čl. 18. st. 2. Zakona o obveznim odnosima nižestupanjski sudovi su odbili tužbeni zahtjev, a time su materijalno pravo pravilno primijenili. Odredbom čl. 18. st. 2. ZOO-a propisano je da je sudionik u obveznopravnom odnosu dužan u izvršavanju obveze iz svoje profesionalne djelatnosti postupati s povećanom pažnjom, prema pravilima struke i običajima (pažnja dobrog stručnjaka). Međutim, činjenica što tuženik prilikom ultrazvučnih pregleda nije otkrio malformacije kod djeteta tužitelja doista nije u uzročnoj vezi sa njihovim postojanjem, jer su one postojale od samog početka trudnoće prvotužiteljice i povećavale se razmjerno rastu ploda, a kako one ne predstavljaju apsolutnu indikaciju za prekid trudnoće niti postoji mogućnost njihova izlječenja za vrijeme intrauterinog života, pa i u slučaju da ih je tuženik otkrio, one ne bi mogle biti uklonjene niti smanjene štetne posljedice zbog njihova postojanja."

40 Faure, M., op. cit., str. 19. 
stoji u adekvatnoj kauzalnoj vezi s nastalom štetom koja zadire u zdravstvenu sferu pacijenta. Povreda dužne pažnje ukazuje na postojanje krivnje kao subjektivnog elementa protupravnosti. Prema tome, skrivljeno bi postupio svaki liječnik koji bi medicinski tretman provodio s pažnjom tek osrednjeg ili prosječnog stručnjaka, a u odnosu na postavljeni standard pažnje dobrog stručnjaka, a što je detaljno eksplicirano u prethodnom poglavlju. Dakle, medicinski tretman može biti poduzet contra legem artis, odnosno, mala praxis, tj. kao skrivljeno, nesavjesno postupanje liječnika ako je medicinski zahvat nad pacijentom poduzet bez odgovarajućeg stupnja stručne vještine, pažnje i kompetencije ili kao propuštanje poduzimanja radnji koje su medicinski zahvat i koje su trebale biti obavljene sukladno pravilnom i opravdanom standardu dužne pažnje i stručne vještine liječnika temeljene na kompetentnom profesionalnom mišljenju liječnika. ${ }^{41}$

Protupravnost štetne radnje postoji kada je povrijeđena pravna norma čija povreda ipso iure zahtijeva popravljanje štete koja stoji u uzročno-posljedičnoj vezi s protupravnim ponašanjem. Posebne pretpostavke odštetne odgovornosti karakteristične su za pojedinu vrstu odgovornosti. Tako je za ugovornu odgovornost osim općih pretpostavki, potrebno još i postojanje ugovorne obveze i njezina povreda. Za subjektivnu, odgovornost koja se primjenjuje na štete koje nastanu pružanjem zdravstvenih usluga, zahtijeva se krivnja štetnika. Prema tome, u postupku naknade štete zbog liječničke pogreške sudovi ispituju postojanje općih i posebnih pretpostavki građanskopravne odgovornosti. ${ }^{42} \mathrm{U}$ postupku naknade štete štećenik će morati dokazati postojanje pravnorelevantne štete koja je u uzročno-posljedičnoj vezi s poduzetim medicinskim tretmanom. Pritom ne mora dokazivati subjektivni element krivnje jer se ona presumira.

\subsubsection{Tipičan modus povrede medicinskog standarda-liječnička pogreška}

Liječnička pogreška (engl. medical malpractice) de facto je takav oblik štetne radnje pri kojem liječnik nije primijenio medicinski postupak utemeljen na aktualnim spoznajama medicinske znanosti, a koji je s obzirom na konkretne okolnosti objektivno bio neophodan, odnosno, ako ga je primijenio ali nepravilno, te slijedom toga nije postupio s odgovarajući stupnjem pozornosti koja se općenito zahtijeva od savjesnog liječnika. ${ }^{43}$ Praksa poznaje različite modalitete liječničke pogreške: (1) pogreške unutar organizacijskog procesa; (2) pogreške pri preuzimanju pacijenta; (3) pogreške koje su posljedica nedostatne suradnje s obzirom na horizontalnu i

41 Giesen, D., op. cit., str. 105.

42 Vrhovni sud Republike Slovenije, II Ips 712/2004 od 16.02.2006. „Tužitelj u obrađivanom predmetu podlogu za odštetu zasniva na navodnom postojanju liječničke pogreške. Kao liječnička pogreška može se odrediti takvo postupanje liječnika koje predstavlja uzrok povrede i istovremeno je u suprotnosti sa standardima stručnog postupanja (postupanje contra legem artis). U skladu s pravilom iz članka 154., stavak prvi ZOO-a je dokazni (a također i u odnosu na tvrdnje) teret glede izvornosti civilnog delikta podijeljen na obje stranke. Tužitelj mora tvrditi i dokazati činjenice koje dokazuju postojanje nedopuštenog štetnog čina, nastanak štete te uzročnu vezu među njima. Na tuženoj stranci je teret dokaza i tvrdnji da liječnik za to nije kriv, to jest da svojim postupanjem nije prouzročio štetnu posljedicu.“”

43 Ferrara, S. D., Boscolo-Berto, R., Viel, G. (ur.), op. cit., str. 122. 
vertikalnu distribuciju poslova; (4) izostanak medicinskog tretmana - namjerno ili nemarno propuštanje poduzimanja neophodnog medicinskog tretmana; (5) nepravilan medicinski tretman - terapija koja je u neskladu s aktualnim medicinskim spoznajama. Tipične su liječničke pogreške: (1) nedostatnost kliničkog, laboratorijskog i drugog istraživanja; (2) pogrešna dijagnoza; (3) pogrešna indikacija; (4) nedostatak kontrole; (5) pogrešna terapija; (6) pogrešne kirurške tehnike; (7) neprepoznavanje medicinskih komplikacija; (7) pogrešna ili nedostatna higijena; (8) neispravna medicinska oprema i (9) pogreške u rukovanju s injekcijama, infuzijom i transfuzijom. ${ }^{44}$

Slijedom iznesenog, liječničke pogreške mogu se summa divisio podijeliti na: (1) dijagnostičke liječničke pogreške; (2) terapijske liječničke pogreške koje uključuju pogreške $u$ terapiji i pogreške u provođenju medicinskih zahvata (invazivnih i neinvazivnih) te na (3) komunikacijske liječničke pogreške koje nastaju u komunikaciji, odnosno izostanku pravilne komunikacije između liječnika i pacijenta ili liječnika i medicinskog osoblja, bez obzira na aktivni (činjenje, facere) ili pasivni (propuštanje, non facere) modus počinjenja. ${ }^{45}$

U hrvatskom pravu ne postoji jasna definicija termina liječničke pogreške. Međutim, sadržaj pojma pravno relevantne liječničke pogreške može odrediti negativno, enumeracijom obveza liječnika tijekom medicinskog tretmana nad pacijentom, koje su utvrđene zakonskim i strukovnim propisima te uvriježenim medicinskim običajima (consuetudo). Naime, u supstratu liječničke pogreške stoji postupanje liječnika protivno pravilima zdravstvene struke, odnosno, postupanje contra legem artis ili tzv. mala praxis, kao i postupanje liječnika protivno moralnim i etičkim načelima te suvremenim medicinskim standardima. Hrvatska pravna znanost je liječničku pogrešku definirala kao postupanje liječnika u okviru medicinskog zahvata nad pacijentom, protivno pravilima zdravstvene struke te njenim moralnim $i$ etičkim načelima, odnosno kao postupanje liječnika koje je u neskladu s provjerenim standardima suvremene medicinske znanosti, a što je rezultiralo povredom pacijentova zdravlja ili života, $t j$. povredom prava osobnosti ${ }^{46}$ Valja uočiti da pojam liječničke pogreške per extensum obuhvaća i medicinske zahvate koji se provode bez pristanka pacijenta - samovoljno liječenje i to neovisno o mogućnosti da je liječenje u svemu provedeno prema pravilima medicinske profesije, jer zbog povrede prava pacijenta na suodlučivanje (informirani pristanak) izravno nastupa šteta u vidu povrede prava na tjelesni integritet, kao jednog od zaštićenih prava osobnosti pacijenta.

\subsection{Popravljanje štete prouzročene povredom medicinskog standarda}

\subsubsection{Odštetnopravni postupak radi naknade štete prouzročene povredom medicinskog standarda}

Građanskopravna odgovornost za liječničku pogrešku utvrđuje se u parničnom

44 Dettmeyer, R., Madea, B., Haftpflicht und Behandlungsfehler, u: Praxis Rechtsmedizin (ur. Madea, B.), 2. ed., Berlin/Heidelberg, Springer, 2007., str. 577-581.

45 Vojković, H., Građanskopravna odgovornost za liječničku pogrešku, doktorska disertacija, Zagreb, Pravni fakultet, 2013., str. 165.

46 ibid., str. 140. 
postupku kao osnovnim pravno-zaštitno sudskim sredstvom, kojim se ostvaruju prava na naknadu štete. Parnični se postupak pokreće tužbom tužitelja, u pravilu neposrednog oštećenika (bivšeg pacijenta), a katakad tužbom koju su podnijele treće osobe koje su ovlaštene zahtijevati naknadu štete. Aktivno legitimirani u tužbi zahtijevaju kondemnatornu pravnu zaštitu, odnosno isplatu određenog novčanog iznosa koji bi bio materijalno zadovoljenje na ime pretrpljene štete. Pravna zaštita može biti usmjerena i na otklanjanje nedostataka u obavljanju dijagnostičkog ili terapijskoga medicinskog tretmana, odnosno na naturalnu restituciju ako za to postoje realne pretpostavke, ali slučajevi tako postavljenoga tužbenog zahtjeva u praksi iznimno su rijetki.

Kada je u pitanju spor o problematici medicinskog standarda, a što je središnje pravno pitanje u pokrenutom parničnom postupku, sud odlučuje oslanjajući se na nalaz i mišljenje vještaka medicinske struke koji će odrediti aktualni standard medicinskog postupanja i vrednovati sporni slučaj. Pri izradi nalaza i mišljenja vještak će glavne uporišne točke naći u medicinskoj dokumentaciji, aktualnim protokolima, vodičima dobre prakse, a nekad i u običajnim pravilima medicinske prakse. Do primjene ovoga dokaznog sredstva u pravilu neće doći kad se radi o posebno grubim liječničkim pogreškama, tj. kad su pravno relevantne činjenice poznate same po sebi bez potrebe dodatnog izvođenja dokaza, odnosno kad su ispunjene pretpostavke za primjenu dokazne olakšice na prvi pogled, sukladno načelu res ipsa loqitur. Od sudova se očekuje da kritički vrednuju nalaze i mišljenja vještaka te da osiguraju da vještak pravilno razumije svoju ulogu pomoćnika u procesu utvrđenja pravno relevantnih medicinskih činjenica iz kojih će sud izvesti pravne zaključke. ${ }^{47}$ Naime, u okviru dokaznoga postupka postoji temeljna podjela rada na način da se vještak očituje o stručnim, činjeničnim pitanjima, quaestio facti, koja se pojavljuju u parnici, dok sud odlučuje o pravnim pitanjima, quaestio iuris. Dakle, neovisno o stručnoj vrijednosti vještačkog nalaza i mišljenja, vještakova uloga da pomaže sudu pri izvođenju pravnog zaključka nikada nije odlučujuće kad je u pitanju pravna ocjena eventualne liječnikove nepažnje, jer je za dokaz postojanja liječničke pogreške odlučujuće osobno uvjerenje suda, a ne stupanj uvjerenja sudskoga vještaka. ${ }^{48}$ Izrečeno stajalište pravne teorije potvrđeno je u praksi hrvatskih sudova:

U skladu s čl. 154. st. 1. ZOO-a, smatra se da je aktivan, štetan zahvat medicinskim alatom, - trokarom - u vanjski dio stijenke crijeva nebrižno postupanje. Na tuženoj stranci je dakle dokazni teret da štetan kontakt trokara s vanjskim dijelom crijevne stijenke nije posljedica liječnikova nemara, nego ostalih (konkretno navedenih) okolnosti ili da se čak može pripisati i slučaju. Odluka da tužiteljici takvim zahvatom ukloni jajovod bila je u skladu sa stručnom doktrinom. Takav zahvat je prema mišljenju vještaka izvanredno siguran. Kod tužiteljice je došlo do komplikacija jer je krvarila iz ostatka uklonjenog jajovoda, a bilo je oštećeno i tanko crijevo te ožilje potpore crijeva. Vještak je objasnio da je povreda crijeva jedna od najčešćih komplikacija laparoskopske kirurgije, a njezina čestina je od 0,25 do 1 tisućinke. Uzroci da svejedno dolazi do povreda crijeva u većini slučajeva ostaju neobjašnjeni. Prema mišljenju vještaka takva povreda se može dogoditi i iskusnom operateru uz najveću moguću brižnost. Ipak, sud nije prihvatio taj dio vještačkog mišljenja i zaključio je da je do povreda crijeva kod tužiteljice došlo zbog premale brižnosti operatera u svom radu. Sud je smatrao da tužena stranka nije dokazala da je operater njezina osiguranika prilikom obavljanja svoga posla postupao tako kako je bilo potrebno.

47 Giesen, D., op. cit., str. 118.

48 Radišić, J., op. cit., str. 326. 
Ipak, iako o pitanju medicinskog standarda odlučuje sud, utvrđivanje standarda medicinskog postupanja de facto je uvelike posredno u kompetenciji liječnika, a ne suda. U osnovi, na vještaku je zadatak da sudu posreduje određeno stručno znanje kojim sud ne raspolaže, ali bez kojeg ne može ocijeniti iznesene dokaze. Pritom sud slobodno ocjenjuje nalaz i mišljenje medicinskog vještaka, a granica slobodne ocjene suda podudara se s mjerom u kojoj raspolaže potrebnim stručnim znanjem. Medicinski vještak ima tri zadatka: razjasniti medicinsko stanje stvari; ocijeniti je li postupak tuženog liječnika u skladu s važećim medicinskim standardom; u slučaju odstupanja od medicinskog standarda, ocijeniti, je li taj postupak prouzrokovao oštećenje pacijentovog zdravlja i bi li do štete došlo da je medicinski tretman pružen sukladno zahtijevanom medicinskom standardu postupanja. ${ }^{49} \mathrm{U}$ tom smislu od vještaka se očekuje da u svom izvještaju jasno naznači smatra li da je praksa koju primjenjuje tuženik u skladu s praksom koja je prihvaćena kao ispravna odgovornih medicinskih stručnjaka na odgovarajućem polju medicine.$^{50}$ Osim toga, smatra se bitnim da vještaci nedvosmisleno predoče sudu situacije u kojima postoji tek mogućnost uzročne veze, od onih u kojima postoji veća ili manja vjerojatnost, odnosno da ukažu na situacije gdje je izvjesno postojanje kauzaliteta. ${ }^{51}$

\subsubsection{Primjena instituta slobodne ocjene pri određivanju naknade štete}

Nakon što je utvrdio da parničnoj stranci u odštetnopravnom postupku pripada pravo na naknadu štete (na novčanu svotu ili na zamjenjive stvari), ali se visina svote odnosno količina stvari ne može utvrditi ili bi se mogla utvrditi samo s nerazmjernim teškoćama, sud će o tome odlučiti prema slobodnoj ocjeni. ${ }^{52} \mathrm{U}$ praksi će sud po svom uvjerenju odlučiti koje činjenice treba uzeti kao dokazane, a to svoje uvjerenje može formirati tek nakon što je proveo savjesnu i brižljivu ocjenu svakoga dokaza posebno i svih dokaza zajedno, uzimajući u obzir i rezultate cijelog postupka te tako formirao uvjerenje na razini izvjesnosti. ${ }^{53}$

U pogledu zahtjeva za naknadu neimovinske štete, zakonodavac je predvidio dosuđivanje novčanog iznosa na ime pravične novčane naknade. Hrvatsko pravo definira neimovinsku štetu kao povredu prava osobnosti oštećenika, a ako se navedena povreda subjektivnog prava faktično ostvari sud će, ako nađe da to težina povrede i okolnosti slučaja opravdavaju, dosuditi pravičnu novčanu naknadu, nezavisno od naknade imovinske štete, a i kad nje nema. Pritom će voditi računa o jačini i trajanju povredom izazvanih fizičkih boli, duševnih boli i straha, cilju kojemu služi ta naknada,

49 Gnjidić, Ž., Vještačenje profesionalne odgovornosti. Skup Medicinski, pravni i ekonomski pogledi na profesionalnu odgovornost u zdravstvu i osiguranje od odgovornosti, Šibenik, Udruga poslodavaca u zdravstvu, 2007.

50 Presuda iz engleske sudske prakse u predmetu Sharpe v. Southend Health Authority, MLC 0661 (2000), Medical negligence, < http://www.medneg.com/Case/CaseList.aspx>, 8. veljače 2013.

51 Dika, M., Rješavanje sporova za naknadu štete zbog liječničke greške, Skup Medicinski, pravni i ekonomski pogledi na profesionalnu odgovornost u zdravstvu i osiguranje od odgovornosti, Šibenik, Udruga poslodavaca u zdravstvu, 2007.

52 Čl. 219.-229. Zakona o parničnom postupku, Službeni list SFRJ, br. 4/1977, (...); NN, br. 53/1991, (...) 89/2014 (dalje: ZPP).

53 Čl. 8. ZPP-a 
ali i o tome da se njome ne pogoduje težnjama koje nisu spojive s njezinom naravi i društvenom svrhom..$^{54}$ Iznos pravične novčane naknade na ime neimovinske štete sud će redovito odmjeriti po slobodnoj ocjeni, pri čemu je slobodna ocjena u funkciji kvantifikacije pravične novčane naknade kao kriterija materijalnog prava, dok bi kao činjenično pitanje po slobodnoj ocjeni redovito odmjeravao intenzitet i trajanje fizičkih i duševnih bolova i straha. ${ }^{55}$ Tipičan slučaj koji se u nastavku iznosi ukazuje na pojavne oblike povrede prava osobnosti za koju se odmjerava pravična novčana. Tako je tijekom dokaznog postupka sud utvrdio postojanje višestruke liječničke pogreške u terapiji koja je bila primarno prouzrokovana nestručno provedenim zahvatom uvođenja katetera kroz venu što je dovelo do lezije stijenke arterije:

U postupku je utvrđeno: - da je tužitelj bio primljen kod tuženika 21. rujna 1997. godine, te je tužitelju izvršena pretraga koronarografije, - da je prilikom izvršenja pretrage i prilikom uvođenja katetera kroz desnu femoralnu venu došlo do lezije stijenke arterije u većem obimu, a što je uzrokovalo stvaranje hematoma u toj regiji s kompresijom femoralnog živca koji komunicira s arterijom a što je prouzročilo neizdržljive boli u nozi - da je po pravilima medicinske struke valjalo operacijski riješiti zatvaranje arterije, a što nije učinjeno, - da je kod tužitelja vrš̌na samo punkcija hematoma i to nakon par dana na inzistiranje tužiteljeve supruge, a što nije riješilo postojeće stanje i time nije rasterećen pritisak zgrušane krvi i novo pridošle, a što je sve dovelo do lezije femoralnog živca desne noge, time da je to stanje definitivno, - da je lezija femoralnog živca u direktnoj vezi sa rađenim pretragama i posljedice koje su nastale nakon tih pretraga, a da prijašnje zdravstveno stanje tužitelja na to nije imalo utjecaja, - da je kod tužitelja trebalo odmah reagirati kod početnog nastanka hematoma jer bi se na taj način izbjegle posljedice. Zbog nastupjelih posljedica tužitelj je trpio fizičke boli jakog intenziteta 2-3 dana, srednjeg intenziteta 3 mjeseca i manjeg intenziteta 6 mjeseci. U vezi sa nastalim posljedicama tužitelj je trpio primarni jaki strah oko 1,5 sati, zatim sekundarni jaki strah 12 dana, srednji sekundarni strah 6 tjedana, te kasni strah 4 mjeseca. Nastupjele posljedice smanjile su životnu aktivnost tužitelja za $35 \%$. Tužitelj je po zanimanju diplomirani pravnik, a u vrijeme štetnog događaja bio je u dobi od 67 godina. Kod tužitelja je nastupila naruženost srednjeg do teškog stupnja koja se manifestira na primjetnom šepanju, držanjem za rukohvat pomoću kojeg se vuče uz ili niz stubište, te primjetnom razlikom u debljini desne i lijeve noge u natkoljenicama pri nošenju kratke odjeće i kupanja, te izvrtanju koljena unazad pri stajanju. Tužitelju je nakon izlaska iz bolnice bila potrebna tuđa pomoć i njega mjesec dana 8 sati dnevno, 3 mjeseca 4 sata dnevno, a zatim trajno 2 sata dnevno. Visina te štete iznosi $10,00 \mathrm{kn}$ po satu pružane usluge. $U$ vezi sa liječenjem od nastalih posljedica tužitelj je imao troškova u iznosu od 15.840,00 kn. Nalazeći da je šteta tužitelju nastala zbog propusta osoblja tuženika prilikom vršenja pretrage koronarografije nižestupanjski sudovi su zaključili da je tuženik odgovoran tužitelju za naknadu štete, a drugostupanjski je sud pravilno zaključio da tuženik u konkretnom slučaju za štetu odgovara temeljem pretpostavljene krivnje, a ne temeljem uzročnosti kako smatra prvostupanjski sud. ${ }^{56}$

Kod naknade imovinske štete oštećenik ostvaruje pravo na naknadu obične štete i naknadu izmakle koristi, dok se visina naknade određuje prema cijenama u vrijeme donošenja sudske odluke, osim ako zakon određuje što drugo. Pri ocjeni visine izmakle koristi uzima se u obzir dobitak koji se mogao osnovano očekivati prema redovitom tijeku stvari ili prema posebnim okolnostima, a čije je ostvarenje spriječeno štetnikovom radnjom ili propuštanjem..$^{57} \mathrm{U}$ situaciji kad se imovinska šteta može kvantificirati sud bi mogao po slobodnoj ocjeni utvrditi u čemu se sastoji

54 Čl. 1100. ZOO-a.

55 Dika, M., op. cit.

56 VSRH, Rev-540/03-2 od 17. prosinca 2003.

57 Čl. 1089. ZOO-a. 
gubitak. Na isti bi se način utvrđivao novčani ekvivalent prouzrokovane štete, kao štete u „drugom agregatnom stanju“, ako se ne bi mogao odrediti drukčije ili bi to bilo moguće samo uz nesrazmjerne teškoće. Sud će in abstracto, slobodnom ocjenom utvrditi novčani iznos na ime naknade štete tek ako se novčani ekvivalent pretrpljene štete ne bi mogao utvrditi prema cijenama u vrijeme donošenja sudske odluke ili prema drugim zakonskim kriterijima. Utvrđivanje visine novčanog iznosa naknade u režimu slobodne ocjene suda redovito se zbiva kad se određuje visina izmakle koristi, a mnogo rjeđe kad se radi o ustanovljenju visine obične, stvarne štete.

Pozitivno pravo ustanovljava pravo oštećenika na potpunu naknadu štete koja mu je nanesena i to tako da sud uzimajući u obzir i okolnosti koje su nastupile poslije prouzročenja štete, dosuđuje naknadu u iznosu koji je potreban da se oštećenikova materijalna situacija dovede u ono stanje u kojem bi se nalazila da nije bilo štetne radnje ili propuštanja. ${ }^{58}$ Kako bi se ostvarilo navedeno subjektivno pravo oštećenika, sud prije određivanja naknade mora utvrditi u čemu bi se in concreto sastojala materijalna situacija ako nije bilo nastupa štetne radnje koja je u kauzalnom odnosu s pravno relevantnom štetom.

\subsubsection{Karakteristični slučajevi iz hrvatske i poredbene prakse po kriteriju tipologije liječničkih pogreški}

\subsubsection{Terapijska liječnička pogreška}

\section{Slučaj 1.}

Vrhovni sud Republike Hrvatske, Rev 876/06-2 od 10. siječnja 2007. - Presuda u predmetu tužitelja 1. Ć. B. i 2. K. B., protiv tuženika Kliničkog bolničkog centra Rijeka:

Operativni zahvat razbijanja bubrežnih kamenaca vibracijom putem ultrazvuka u punoj anesteziji izvršen je na pacijentu Z. B. Radilo se o rutinskoj operaciji (trajanja 1 do 1,30 h) koja je izvršena u rendgen sali, a ne u operacijskoj sali u okviru koje postoji i soba za buđenje, koja inače služi za kontrolu vitalnih funkcija u ranom postoperativnom periodu. Sama operacija i anestezija protekla je uredno i bez komplikacija. Nakon operacije medicinska sestra je vršila transport bolesnika od rendgen sale do urološkog odjela kat niže s pomoću spremačice. Soba nije imala potrebne instrumente i uređaje za brzu i efikasnu reanimaciju. Medicinska je sestra pri prebacivanju bolesnika s transportnih kolica na krevet uočila plavetnilo na koži i noktima što je znak otežanog disanja, pa je pokušala uspostaviti disanje pomoću ambul balona preko maske $u$ čemu nije uspjela. Telefonom je pozvan dežurni anesteziolog s jedinice intenzivnog liječenja. Anesteziolog je bio udaljen oko 60 metara od urološkog odjela, morao je proći troja vrata, a jedna pritom i otključati da bi došao do bolesnika, te ga je pokušao reanimirati. Bolesnik više nije spontano disao, te je imao slabu srčanu reakciju, pa se pristupilo hitnoj intubaciji i vanjskoj masaži srca. Zatim mu je dan intravenozni adrenalin nakon čega je zamijećena srčana aktivnost uz normalizaciju boje kože. Nakon toga bolesnik je prebačen u jedinicu intenzivnog liječenja na daljnji tretman. Ostao je na životu, ali s posljedicom teškog i nepopravljivog oštećenja mozga (trajno komatozno stanje).

Predmet spora je zahtjev tužitelja za naknadom nematerijalne i materijalne štete (pogrebni troškovi i dr.) zbog smrti bliske osobe.

Prvostupanjskom je presudom odbijen tužbeni zahtjev tužitelja za isplatom štete. Drugostupanjski sud je odbio žalbu tužitelja kao neutemeljenu i u cijelosti potvrdio presudu prvostupanjskog suda. Protiv te presude reviziju su izjavili tužitelji. Vrhovni sud RH je reviziju

58 Čl. 1090. ZOO-a. 
prihvatio kao osnovanu te ukinuo obje presude i predmet vratio na ponovno suđenje. U revizijskoj fazi postupka sporna je odgovornost tuženika, tj. je li zbog propusta medicinskog osoblja u postoperativnom tretmanu kod sada pok. Z. B. došlo do kardiorespiratornog aresta (zastoj srca i prestanak disanja) te posljedično teškog oštećenja mozga zbog nedostatka kisika (atrofija mozga), odnosno jesu li se posljedice mogle spriječiti pravodobnim uočavanjem i bržom reanimacijom. S obzirom na utvrđeno činjenično stanje da je bolesnik ostao na životu, ali s posljedicom teškog i nepopravljivog oštećenja mozga te da je pravilo kod tuženog da se pacijenti nakon razbijanja bubrežnih kamenaca iz rendgen sale odvode u sobu za buđenje, te je uz njih prisutan anesteziološki tehničar koji po potrebi poziva doktora anesteziologa koji je u neposrednoj prisutnosti i da je bolesnik u vrijeme operacije bio star 23 godine bez drugih zdravstvenih teškoća, izraženi pravni stav nižestupanjskih sudova se ne bi mogao prihvatiti kao pravilan, pa ga opravdano pobijaju revidenti u reviziji. Ocjena postoji li uzročna veza ili ne - pravno je pitanje o kojem treba odlučiti sud, a ne vještaci. U konkretnom slučaju proizlazi (prema iskazu medicinske sestre) da je bolesnik transportiran na urološki odjel kada i nije bio u potpunosti razbuđen, a da je pravovremena reanimacija izostala jer nije postojao kontinuirani nadzor i mogućnost hitne intervencije kvalificiranog medicinskog osoblja. Naime, odsustvo liječničke pogreške i uzročne veze postoji kad se štetna posljedica nije mogla svladati usprkos tome što se postupalo s potrebnom pažnjom u skladu s medicinskim standardom, a to je u konkretnom slučaju izostalo. Tuženica se prema shvaćanju Vrhovnog suda ne može ekskulpirati tvrdnjom da zdravstvene tegobe Z. B. treba prihvatiti kao rizik anestezije, a u danim okolnostima nije postupljeno onako kako je trebalo (čl. 170. i 171. ZOO-a), a naše odštetno pravo predmnijeva krivnju štetnika (čl. 154. ZOO-a). Naime, postavlja se pitanje je li u konkretnom slučaju bilo moguće spriječiti kardiorespiratorni arest u postoperacijskoj fazi, a kad se on i pojavio njegovo pravodobno uočavanje i čim brža reanimacija radi otklanjanja fatalne posljedice - ishemičkog oštećenja mozga te je li takvo stanje dovelo i do smrti pacijenta nakon šest godina, s obzirom na to da je utvrđeno, da je Z. B. imao 23 godine, inače zdrav, riječ je o manjem rutinskom operativnom zahvatu, te da je sam tijek operacije i anestezije protekao uredno, odnosno nije utvrđeno da bi se radilo o takvim osobinama organizma i sl. koje se prema postojećem stanju medicinske znanosti nisu mogle predvidjeti, dakle da bi se radilo o sudbinskom ishodu bolesti. Sud je u smislu članka 8. ZPP-a dužan cijeniti sve provedene dokaze, pa tako i nalaz vještaka (kao jedan od dokaza) u svojoj ukupnosti te uzročno posljedičnu vezu utvrđivati za konkretan slučaj cijeneći sve utvrđene okolnosti i činjenice, a ne prihvatiti općenitu konstataciju iz vještačkog nalaza da se radi o iznimno rijetkoj, ali poznatoj komplikaciji, tako da i pravodobna intervencija da je poduzeta (a nije), ne bi morala dovesti do povoljnije reanimacije (dakle neizvjesna je). Naime, upravo u tim slučajevima kad postoji određena dvojbenost o kauzalitetu budući da katkad kauzalitet je vrlo teško i gotovo nemoguće utvrditi odluka o uzročnoj vezi tada se može utemeljiti jedino na dovoljno visokom stupnju vjerojatnosti njezinog postojanja. Kako su sudovi dakle zbog pogrešnoga pravnog pristupa pogrešno primijenili materijalno pravo na temelju članka 395. stavka 2. ZPP-a obje su presude ukinute, pa će se u ponovljenom postupku utvrđivati i ocijeniti upravo okolnosti i činjenice u vezi s uzrokom smrti pok. Z. B., s obzirom na preinačen tužbeni zahtjev.

\section{Slučaj 2.}

Vrhovni sud Austrije, 90b79/07v. od 8. veljače 2008.:

Tužitelj se u bolnici tuženice podvrgnuo operaciji kuka. Pritom je došlo do pogrešnog obavljanja liječničkog posla, a pri dodatnoj operaciji do kršenja obveze informiranja, bez kojeg se tužitelj, u najmanju ruku, ne bi u toj bolnici podvrgnuo drugoj operaciji. Pri prvoj operaciji umjetna čašica kuka je prestrmo ugrađena, tako da je već neposredno nakon operacije došlo do subluksacije i luksacije umjetnog zgloba kuka i time do popuštanja umjetnog trupa kuka. Zbog toga je bila potrebna druga operacija. Tuženica je u prethodnom postupku iznijela prigovor da se kod ugradnje umjetne zglobne čašice nije dogodila liječnička pogreška. Popuštanje trupa, prema njezinim navodima, nastalo je zbog sudbonosne i neizbježne infekcije koja je prouzrokovala slijeganje i zatim popuštanje trupa zgloba kuka. Tvrdila je da je isključivo to sudbonosno popuštanje bilo uzrok druge 
operacije i da je sadašnjem tuženiku pruženo dovoljno informacija.

Prvostupanjski sud naložio je u prethodnom postupku tuženici da tužitelju naknadi materijalnu štetu. Sud je polazio od utvrđenja kako je točno da bi pogrešna ugradnja umjetne čašice mogla imati za posljedicu drugu operaciju, ali da je neposredan uzrok druge operacije bila sudbonosna infekcija koja nije povezana s operacijom. Prema sudu, uz stručno obavljenu drugu operaciju, isključene su kasne i trajne posljedice. Žalbeni je sud dvojio oko tumačenja dokaza prvostupanjskog suda te je, ponavljanjem dokaznoga postupka, došao do drugih utvrđenja. Po njemu, uzrok je druge operacije bila isključivo nestručna prva operacija. Tvrdi da se ne može ustanoviti da je sudbonosna infekcija dovela do slijeganja trupa. Osim toga, drugi je zahvat prouzročio trajni poremećaj funkcionalnosti (insuficijenciju) mišića u blizini zgloba kuka, što je povezano s poremećenim hodom, pri čemu je hodanje na duže relacije moguće svladati samo sa štakom. U svom zahtjevu za obnovu postupka, uloženom žalbenom sudu, podnositeljica zahtjeva (tuženica) za obnovu postupka zahtijevala je da se obnovi postupak poništavanjem presude pokrajinskog suda kao žalbenog suda, da se žalba tužitelja u okviru postupka koji bi se trebao obnoviti ne potvrdi te da se potvrdi presuda Okružnog suda Landeck, da se u obnovi pravnog predmeta potvrdi zahtjev tuženika samo u pogledu isplate odštete u iznosu od 1.750 EUR. Žalbeni sud odbio je tužbu radi obnove postupka. Sud je smatrao da ne postoje zakonski razlozi za obnovu postupka, jer se tužiteljica odnosno podnositeljica zahtjeva za obnovu postupka nije pozvala na činjenice ni na nove dokaze, a da ih nije mogla koristiti i u prethodnom postupku. Stoga je sud s pravom odbio zahtjev za obnovu postupka sukladno $\S 538$ ZPO-u (Zakonu o građanskopravnom postupku).

\section{Slučaj 3.}

Vrhovni sud Republike Slovenije, II Ips 190/2008 od 3. travnja 2008.:

Tužiteljevo lijevo uho bilo je oštećeno tijekom operacije 7. ožujka 1994., koja je bila obavljena pod lokalnom anestezijom. Pri pričvršćivanju proteze, zbog dodira kožastog labirinta u unutarnjem uhu došlo je do udarnog svrdlastog zakretanja tužitelja i do mehaničke povrede jer operater nije uspio pravovremeno izvući instrumente iz uha. Sudovi su utvrdili da kod operacija ovakve vrste obično dolazi do nježnog dodira kožastog labirinta, što kod pacijenata obično uzrokuje samo vrtoglavicu, eventualno povraćanje i pomak glave koji nije tako brz odnosno povezan $\mathrm{s}$ nenadanim podizanjem tijela, da operater ne bi uspio izvući instrument iz operacijskog polja. I u konkretnom slučaju došlo je samo do blagog dodira kožastog labirinta, ali je tužiteljeva reakcija zbog preosjetljivosti njegova kožastog labirinta neuobičajena. Sudovi su ocijenili da je tužiteljev refleksni odaziv po svom intenzitetu više nego znatno premašio uobičajene reakcije pacijenata, te da stoga njegova reakcija nije adekvatna posljedica kontakta medicinskih pomagala s kožastim labirintom i da nastala šteta nije u pravno relevantnoj uzročnoj vezi s liječničkim zahvatom. Budući da je udarni svrdlasti pomak bolesnika tijekom operacije prema dostupnoj literaturi nešto izvanredno, odnosno u njoj nije ni spomenut, događaj operateru prije početka operacije nije bio poznat i predvidljiv i zbog toga mu se ne može prigovoriti nebrižnost ili nestručnost. Sudovi su utvrdili i da je tužiteljeva volja da se obavi timpanoskopija (uvid u šupljinu bubnjića s pomicanjem bubnjića) i stapedektomija (uklanjanje nepokretnog stremena po dijelovima i umetanje proteze na njegovo mjesto). Tužitelju su i više nego što je uobičajeno objašnjene poteškoće zahvata, tijek zahvata i mogućnosti za uspjeh te mu je rečeno da mogu nastupiti posljedice do kojih je, po tvrdnji tužitelja, u konkretnom slučaju došlo (pogoršanje sluha, šum, smetnje ravnoteže itd.) i ako je zahvat izveden u skladu s pravilima struke (iz nalaza nižih sudova).

Prvostupanjski sud je odbacio tužbeni zahtjev. Žalbeni sud je tužiteljevu žalbu odbio i potvrdio presudu prvostupanjskog suda. Protiv navedene presude žalbenog suda, tužitelj je sam i po opunomoćeniku iz svih revizijskih razloga podnio reviziju. Sudovi su i na osnovi izvoda iz udžbenika otorinolaringološke kirurške tehnike zaključili da je u struci, kod operacija takve vrste, prihvatljiva upotreba obje vrste anestezije, da se ponegdje odlučuju za opću, a drugdje za lokalnu anesteziju, tako da je i lokalna anestezija kod ovakvoga zahvata općeprihvaćena. Zbog toga su neutemeljeni revizijski prigovori da se sudovi prema izvodima iz toga udžbenika nisu 
odredili. Stoga je revizijski sud vezan na činjenične nalaze nižih sudova. Uz nalaze nižih sudova da se operacijski postupak odvijao u skladu s prihvaćenom zdravstvenom doktrinom, da se nije odstupalo od ustaljene stručne prakse te da se tužiteljeve izvanredne reakcije nisu mogle predvidjeti, nisu osnovani ni revizijski prigovori da prvotužena stranka nije postupala s potrebnom brižnošću. Tužiteljeva reakcija operateru nije bila poznata i nije mu mogla biti poznata te mu se i po prosudbi revizijskog suda ne može prigovoriti da bi je morao predvidjeti, da bi morao na mogućnost takve izvanredne reakcije upozoriti tužitelja i za zahvat odabrati opću anesteziju ili tužitelju čak omogućiti da sam odabere vrstu anestezije. Budući da su tužene stranke prema nalazima sudova dokazale da je operater u zadanim okolnostima postupao onako kako je bilo potrebno i u skladu s člankom 45. i glede dužnosti pojašnjavanja u skladu s člankom 47. Zakona o zdravstvenoj djelatnosti, za nastalu štetu nisu odgovorne. Takav zaključak ne znači da je za nastalu štetu kriv tužitelj. Šteta je nastala po slučaju i revizija bez značenja naglašava da su sudovi krivnju neopravdano usmjerili na tužitelja. Budući da ne postoje navedeni revizijski razlozi, revizijski sud je na temelju članka 378. ZPP-a odbio reviziju i priložene revizijske troškove.

\subsubsection{Dijagnostička liječnička pogreška}

\section{Slučaj 1.}

VSRH, Rev 1584/1998-2 od 4. veljače 1999. - Presuda u predmetu tužiteljice E. S. i Z. S. protiv tuženika Opće županijske bolnice iz Našica:

Tužiteljica je tri puta liječena kod tužene. Treći je put primljena zbog prijetećeg pobačaja te je učinjena cerclage (radi očuvanja trudnoće). Godine 1985., 27. siječnja, došlo je do pobačaja. Budući da se nije spontano rađala posteljica, učinjeno je manualno ljuštenje posteljice s dodatnom instrumentalnom eksploatacijom maternice. Nakon toga je tužiteljica bila febrilna u opće lošem stanju s laboratorijskim znakovima upale te je 2. veljače 1985. godine premještena u bolnicu u $O$. zbog upale potrbušnice nastale zbog perforacije maternice. Operirana je i izvađena joj je maternica, jajnik i jedan jajovod te joj je zbog komplikacija izveden još i manji kirurški zahvat. Na temelju nalaza vještaka utvrđeno je da je komplikacija nastala tijekom ljuštenja posteljice zbog čega je dolazilo i do krvarenja tijekom trudnoće, da je do prodora maternice došlo na ginekološkom odjelu tužene te da je operacija u bolnici u O. izvršena radi općeg teškog stanja kada je utvrđen povećani uterus s razdorom stijenke i gnojna upala potrbušnice. Posebno je utvrđeno da je pri eksploataciji maternice, nakon pobačaja, došlo do perforacije maternice. Premda je perforacija moguća, nužno ju je prepoznati i pogreška je liječnika tužene što ju nisu prepoznali. Naime, da je prepoznat na vrijeme a mogla se sanirati i ne bi došlo do odstranjenja maternice kod tužiteljice.

Predmet spora je zahtjev tužiteljice za naknadu štete za koju smatra odgovornom tuženu. Presudom suda prvog stupnja djelomično je prihvaćen tužbeni zahtjev te je tužena naložena naknada štete tužiteljici, i to na ime pretrpljenih fizičkih bolova, na ime duševnih boli zbog smanjenja fizičke aktivnosti, za pretrpljeni strah i za buduću nematerijalnu štetu, te je određeno da svaka stranka snosi svoje troškove. Tužbeni zahtjev tužitelja, kojim zahtijeva naknadu štete zbog osobito teškog invaliditeta supruge, odbijen je kao neutemeljen.

Protiv prvostupanjske odluke uložene su žalbe koje su odbijene kao neosnovane te je pravomoćnom drugostupanjskom presudom potvrđena presuda suda prvog stupnja. Protiv drugostupanjske presude tužiteljica i tužena izjavile su reviziju zbog bitne povrede odredaba parničnoga postupka i zbog pogrešne primjene materijalnog prava. Revizija tužene nije utemeljena te je odbijena, dok je revizija tužiteljice samo djelomično osnovana, i to u odnosu na odluku nižestupanjskih sudova o parničnom trošku. Tužiteljica je u tužbi i tijekom postupka tvrdila da je zbog nestručnog rada radnika tuženika pri medicinskim zahvatima poduzetih na tužiteljici pretrpjela štetu. Na temelju činjeničnih utvrđenja tijekom sudskog postupka i prema ocjeni revizijskog suda proizlazi da postoji odgovornost tužene na temelju odredbe čl. 170. Zakona o obveznim odnosima, jer je utvrđeno da postoje propusti u postupanju liječnika tužene zbog kojih tužiteljica ima štetu koju potražuje. Zbog toga reviziju tužene u odnosu na njezinu odgovornost valjalo je odbiti kao 
neosnovanu, a tužena nije u pravu kada u reviziji želi prikazati da činjenično stanje nije pravilno i potpuno utvrđeno, jer se revizija zbog tih razloga ne može izjaviti. Budući da obje nižestupanjske presude sadrže jasne i određene razloge o odlučnim činjenicama nema bitne povrede iz članka 354 . stavka 2. toč. 13. ZPP-a, a nema ni proturječnosti između onoga što se u razlozima o odlučnim činjenicama navodi. Po ocjeni revizijskog suda nižestupanjski sudovi pravilno su primijenili odredbu članka 200. ZOO-a kada su dosudili tužiteljici naknadu.

\section{Slučaj 2.}

Presuda drugostupanjskog suda (suca G. Stevena Ageeja) od 21.4.2006. u povodu žalbe na presudu Okružnog suda grada Suffolka u predmetu Lawrence J. Monahan v. Obici medical management services, inc., br. predmeta 051592:

U utorak ujutro, 28. kolovoza 2001. Monahan, građevinski podizvođač radova, radio je na građevinskom projektu kad je obavijestio svoga nadzornika, Johnnieja Pressona, da se loše osjeća i da vidi dvostruko. Presson je zatim kontaktirao Monahanovu suprugu i organizirao da ga kolega odveze u Wakefield Medical Center (u nastavku: Wakefield) radi liječničkog pregleda. Kad je Monahan došao u Wakefield, ordinacija je bila zatvorena zbog pauze za ručak, ali osoba na prijemnom pultu primila je Monahana u zgradu klinike jer je primijetila da je neobično vruć i znojan. Anita Curl, medicinska sestra, otpratila je Monahana do sobe za pregled. Posvjedočila je da se Monahan činio vruć i umoran i da je hodao sporo i nesigurno. Barbara P. Carr, specijalizirana medicinska sestra, provjerila je Monahanove vitalne znakove i izmjerila krvni tlak koji je iznosio 200/95 mmHg. Carr je nadalje ustanovila da Monahan osjeća vrtoglavicu i da vidi dvostruko. Carrie Wiggins, viša medicinska sestra u Wakefieldu, pregledala je Monahana oko 13:00 sati. Wiggins je provjerila Monahanov karton, dva puta mu izmjerila krvni tlak i izvršila brzi neurološki pregled te utvrdila da je neurološki status normalan. Zaključila je da je Monahan doživio hipertenzijsku krizu i dala mu je Micardis (lijek za regulaciju krvnoga tlaka). Wiggins je posvjedočila da je rekla Monahanu da se odmara do petka, 31. kolovoza 2001., zakazala mu je pregled za dva tjedna radi mjerenja tlaka i unijela u njegov liječnički karton da ako mu se stanje ne popravi, treba doći sljedeći dan. Monahan je napustio Wakefield i otišao do obližnje ljekarne. Curl je promatrala Monahana u ljekarni i rekla da je izgledao jako bolesno i hodao nagnut naprijed, hodao poput nekoga tko je pod utjecajem alkohola i ošamućen. Vratila se u Wakefield i obavijestila o tome Wiggins, koja je izišla van i našla Monahana kako se naslanja na zgradu, te ponovno s njime razgovarala o njegovu stanju. Zatim mu je propisala Meclizine za vrtoglavicu. Bilo je znatne proturječnosti u iskazima o tome što je Wiggins rekla Monahanu da učini kad su razgovarali o njegovom stanju u Wakefieldu. Wiggins je rekla Monahanu da visoki krvni tlak može dovesti do inzulta i da bi morao otići do hitnog odjela bolnice. Kad joj Monahan nije ništa odgovorio, Wiggins je na temelju njegove šutnje pretpostavila da odbija otići do hitnog odjela. Monahan je inzistirao na tome da mu Wiggins nikada nije rekla da mora otići do hitnog odjela i da nikada nije spomenula mogućnost inzulta. Monahanov liječnički karton u Wakefieldu od 28. kolovoza 2001. sadrži zapis da je odbio otići na hitni odjel u ovome trenutku, ali nema drugog unosa u vezi s bilo kojim razgovorom između Wiggins i Monahana o nužnosti njegova odlaska na hitni odjel. Nešto poslije 13:00 sati, osoba na prijemnom pultu telefonirala je Sandri Rickmond, supruzi Monahanova šefa Richarda E. Rickmonda i rekla joj da je Monahan spreman za odlazak iz bolnice. Prema gđi Rickmond, to je sve što joj je javljeno iz Wakefielda. Gđa Rickmond je tada otišla u Wakefield i odvezla Monahana kući. Tijekom vožnje Monahan se žalio na vrtoglavicu i dvostruki vid. Po dolasku kući otišao je u krevet. Gđa Monahan je svjedočila da joj je po dolasku kući suprug rekao kako mu je Wiggins rekla da ode kući, legne i vrati se u petak. Gđa Monahan je na kratko vrijeme izišla iz spavaće sobe, a kad se vratila, našla je supruga na podu pored kreveta. Nakon što nikoga u Wakefieldu nije uspjela kontaktirati telefonom, odlučila ga je odvesti u bolnicu Riverside u Newport News. Tijekom vožnje do bolnice gđa Monahan ponovno je nazvala Wakefield i razgovarala s Curl. Obavijestila je Curl da vozi supruga u Riverside. Curl je posvjedočila da je uputila gđu Monahan da odveze supruga u hitnu službu Smithfield radi transporta do bolnice. Njihov je razgovor naglo prekinut zbog prekida u mobilnoj telefonskoj mreži. Monahanovi su stigli 
u Riverside oko 15:00 sati, a Monahanu je dijagnosticiran inzult. Jedan od Monahanovih liječnika tijekom rehabilitacije, dr. Mark A. Ross, svjedočio je da je kao posljedicu inzulta Monahan razvio trajne probleme s govorom, vidom, kretanjem, mobilitetom i ravnotežom. Ross je dalje svjedočio da je Monahanu potrebna stalna liječnička skrb radi sprječavanja ponovnog inzulta i da ga se ne može ostaviti samoga dulje vrijeme te računati s time da će se samostalno valjano skrbiti o sebi. Stručnjak za ocjenu radne sposobnosti svjedočio je da je inzult ostavio Monahana nesposobnog za obavljanje profitabilnog zaposlenja s minimalnim ili većim dohotkom zbog problema koje ima s hodanjem, ravnotežom, komunikacijskim teškoćama i umorom.

Monahan je podnio tužbu, koju je kasnije dopunio, tvrdeći da je tuženik propustio pružiti mu odgovarajuću liječničku skrb 28. kolovoza 2001., i da je zbog nemarnog postupanja pretrpio inzult. Monahan je tvrdio da je bolnica Obici odstupila od utvrđenih standarda dužne pažnje jer je Wiggins propustila pravilno dijagnosticirati Monahanovo stanje i pobrinuti se da dobije hitnu medicinsku skrb koja mu je trebala radi sprječavanja ili smanjenja štetnih posljedica inzulta. Monahan je tražio naknadu štete. Ni temelji Obicijeve obrane u odgovoru na tužbu niti dopunjeni temelji obrane nisu postavili pitanje Monahanova propuštanja smanjenja vlastite štete kao obrane. Osim poricanja navoda sadržanih u petitu Monahanove tužbe, bolnica Obici iznijela je afirmativnu obranu kontributivnog nemara i preuzimanja rizika. Nakon što su stranke u postupku predstavile svoje dokaze poroti, Monahan je predložio sudu da uputi porotu da zanemari navode o postupcima gđe Monahan kod transporta supruga u bolnicu Riverside, a ne u bližu bolnicu. Odvjetnik bolnice Obici unakrsno je ispitao gđu Monahan o njenoj odluci da odveze supruga u Riverside iako je udaljeniji od drugih dviju ustanova hitne pomoći. Gđa Monahan je priznala da je vozila u Riverside, mada se on nalazi malo dalje nego Obici. Priznala je i da je izabrala ne stati usput u hitnoj službi u Smithfieldu. Ispitan je i dr. J. Gordon Burcha, jedan od stručnih vještaka tužitelja, o vremenu koje je trebalo gđi Monahan da se doveze do Riversidea. Navedeno je kako je istina da nema stručnjaka koji je rekao da je nastala dodatna šteta zbog odluke da se pacijent odveze u Riverside. Taj je dokaz bitan jer Monahanova teorija o nemaru polazi od pitanja pravovremenog zaprimanja na hitni odjel. Suprotno Monahanovu prigovoru, prvostupanjski sud dao je uputu poroti kako je Obici zahtijevao da tužitelj ima dužnost smanjiti štetu. Ako tužitelj nije razumno postupao da bi štetu sveo na najmanju moguću mjeru i ako je, slijedom toga, pridonio da šteta bude veća nego što bi inače bila, tada ne može dobiti naknadu za povećani dio štete.

Porota je donijela odluku u korist Monahana dodijelivši mu naknadu štete. Prvostupanjski je sud donio rješenje u skladu s odlukom porote 15. travnja 2005. godine, na koje je Monahan prigovorio na osnovi uputa o doprinosu oštećenika vlastitoj šteti i odbijanja brisanja svjedokova iskaza o izboru bolnice kao valjanog dokaza o doprinosu oštećenika vlastitoj šteti. Monahan se žalio po tri osnove. Prvo, da je prvostupanjski sud pogriješio kada je odlučio da doprinos oštećenika vlastitoj šteti nije afirmativna obrana koja se mora izrijekom navesti da bi se mogla upotrijebiti tijekom iznošenja obrane. Drugo, da je prvostupanjski sud pogriješio u odbijanju Monahanova prijedloga brisanja dokaza da je njegova supruga izabrala odvesti ga u Riverside umjesto u bližu bolnicu. Treće, da je prvostupanjski sud pogriješio nalazeći dovoljno dokaza za davanje upute poroti o doprinosu oštećenika vlastitoj šteti. U ovome slučaju nema dovoljno dokaza u potporu pravne upute o doprinosu oštećenoga vlastitoj šteti jer nema dokaza o bilo kakvom nemaru od strane Monahana nakon Wigginsinog pregleda. Wigginsino svjedočenje jasno ukazuje da je dala Monahanu izbor između odlaska na hitni odjel i odlaska kući. Neosporavani dokazi pokazuju da je Monahan izabrao jednu od opcija koje mu je ponudio zdravstveni djelatnik, sestra Wiggins. Netko ga je odvezao kući i legao je u krevet. Nakon što mu je supruga došla kući, njegovo se stanje pogoršalo i odvezen je na odjel hitne pomoći, kako mu je Wiggins i sugerirala. Zbog toga što je Wiggins ponudila Monahanu alternativna rješenja, odlazak na hitni odjel ili kući jer je Monahan poslušao taj savjet i izabrao otići kući, njegova odluka ne može biti osnova za davanje upute o doprinosu oštećenoga vlastitoj šteti. Monahan nije postupio suprotno savjetima koje je dobio od zdravstvenog djelatnika, već je izabrao jedno od ponuđenih rješenja. Stoga se tužitelju ne može pripisati nikakav nemar koji bi ukazao na njegovo propuštanje ublažavanja štetnih posljedica, jer je postupio u skladu sa savjetom Wiggins. Prvostupanjski je sud stoga pogriješio odobrivši Obiciju uputu o doprinosu oštećenoga 
vlastitoj šteti, jer nije bilo dokazne osnove za to. Slijedom toga, ne može se reći da je odluka prvostupanjskog suda o davanju uputa poroti o dužnosti tužitelja da ublaži štetu bila prihvatljiva. Mora se uzeti u obzir da je razmatranje porote bilo pogođeno nevaljano danom uputom o smanjenju štete. Obici nije za temelj žalbe uzeo presudu prvostupanjskog suda o svojem nemarnom postupanju. Ipak, to pitanje se nije ni razmatralo te je potvrđeno rješenje prvostupanjskoga suda o odgovornosti na strani Obicija. Nakon ponovnog suđenja, rješenje o odgovornosti ostat će obvezujuće za Obici, a Monahan neće morati dokazivati nemar društva Obici. Sud je potvrdio i onaj dio rješenja koji se odnosi na to da Obici nije trebao posebno navesti doprinos oštećenoga vlastitoj šteti kao prethodni uvjet iznošenja te obrane. Sud je poništio dio rješenja o naknadi štete jer je bila pogreška dati upute o doprinosu oštećenoga vlastitoj šteti i ne odobriti zahtjev za brisanjem dokaza vezano za odluku o odvoženju Monahana u Riverside. Stoga se predmet vraća na ponovni postupak samo u pogledu pitanja naknade štete.

\section{Slučaj 3 .}

Vrhovni zemaljski sud u Düsseldorfu, presuda od 6. ožujka 2003., Versicherungsrecht, br. 30/2003, str. 1310-1312.:

Zbog crvenila i krvarenja bradavice na desnoj dojci tužiteljica je posjetila tuženu koja je radila kao liječnica za ženske bolesti. Liječnica joj je dijagnosticirala mamilitis i propisala liječenje određenom kremom. Pritom je rekla pacijentici da ponovno dođe za 14 dana, ako za to vrijeme crvenilo i krvarenje ne iščeznu. Pacijentica je ponovno došla kod iste liječnice koja je potvrdila dijagnozu i ponovila joj terapiju. Uputila ju je i liječniku radiologu radi mamografije, ali se pacijentica nije podvrgnula tom pregledu. Tek po preporuci liječnika za kožne bolesti, pacijentica je zamolila tuženu liječnicu da joj da novu uputnicu za radiologa, kod kojega je otišla. Obavljena joj je mamografija koja je potaknula sumnju na karcinom dojke, a histološki pregled je potvrdio multicentrični karcinom dojke. Obavljena je radikalna operacija dojke (mastektomija) na koju se nadovezala kemoterapija i tretman zračenja.

Predmet spora je zahtjev tužiteljice za naknadom štete zbog pretrpljenih bolova radi propusta dijagnostičkih mjera, tj. kasno postavljene dijagnoze. U tužbi je rečeno da su promjene na desnoj dojci morale navesti tuženu liječnicu na poduzimanje daljnjih dijagnostičkih mjera te se tužena liječnica, po navodima u tužbi, morala pobrinuti za što skoriju kontrolu putem nalaza. Da je to učinila, ne bi došlo do operacije dojke i terapije. Tužiteljica je zbog posljedica operacije pokušala izvršiti samoubojstvo pa je zato podvrgnuta i psihijatrijskom liječenju.

Prvostupanjski je sud osudio tuženu da na ime naknade štete zbog pretrpljenih duševnih bolova isplati naknadu tužiteljici, a njena žalba Višem zemaljskom sudu u Düsseldorfu nije imala uspjeha. Presuda upućuje na to, da ako kod pacijentice postoji upadljiv klinički nalaz (crvenilo i krvarenje bradavice na desnoj dojci), pri čemu se ne može isključiti sumnja na tumorsko oboljenje, pogrešno je da ordinirajući liječnik ginekolog kaže pacijentici da ponovno dođe k njemu radi kontrolnog ispitivanja samo ako ne nastupi poboljšanje nastalih promjena na dojci. Time je ocjena medicinskog nalaza, na nedopustiv način, prepuštena pacijentu. U slučaju osnovane sumnje na karcinom dojke, neizostavno je potrebno izvršiti biopsiju i potom obaviti ispitivanje tkiva. Provođenje mamografije (rendgensko snimanje dojke) nije dovoljno. Ako ginekolog ne obavijesti svoju pacijenticu o konkretnoj sumnji na karcinomsko oboljenje dojke i o potrebi hitnog odgovarajućeg dijagnostičkog razjašnjenja, to se postupa kao grubi propust. Odbijanje provođenja hitne dijagnostičke mjere od strane pacijentice treba zabilježiti u njenu medicinsku dokumentaciju.

\subsubsection{Atipične liječničke pogreške}

Slučaj 1.

Vrhovni sud RH, presuda u predmetu tužiteljica J. K., M. K., K. O., LJ. G i S. B. protiv tuženika Doma zdravlja Slavonski Brod: 
Tužiteljice J. K., M. K., K. O., LJ. G i S. B. su 16. travnja 2002. izgubile supruga i oca A. K., koji je bio pacijent Doma zdravlja Slavonski Brod. Djelatnici Hitne pomoći prevozili A. K. od kuće do zdravstvene ustanove radi dijalize. Kod prijevoza su u sudskom postupku utvrđene sljedeće nepravilnosti: transportna kolica nisu imala odgovarajuće remenje za fiksaciju bolesnika i transport je vršen protivno pravilima struke te je A. K. pri transportu pao s nosila i dobio teške ozljede od kojih je kasnije preminuo.

Predmet spora je zahtjev za naknadom materijalne i nematerijalne štete zbog smrti bliske osobe, za koju smatraju odgovornim tuženika.

Presudom suda prvog stupnja naloženo je tuženiku naknaditi tužiteljicama štetu s pripadajućim zateznim kamatama i parnični trošak. Drugostupanjskom presudom žalba tuženika odbijena je kao neosnovana i potvrđena je prvostupanjska presuda. Protiv pravomoćne drugostupanjske presude tuženik je izjavio reviziju zbog bitnih povreda odredaba parničnog postupka i zbog pogrešne primjene materijalnog prava. Revizija je odbijena kao neutemeljena člankom 393. ZPP-a, kao i zahtjev tužiteljica za naknadom troškova odgovora na reviziju. Štetni je događaj nastao isključivo zbog propusta djelatnika tuženika pri prijevozu sada pok. A. K. na dijalizu te je revizijom zaključeno da su nižestupanjski sudovi pravilno zaključili da je tuženik u cijelosti odgovoran za predmetnu štetu prema odredbi članka 170. stavka 1. Zakona o obveznim odnosima.

\section{Slučaj 2.}

Savezni vrhovni sud Njemačke, presuda od 5. ožujka 1985., Medizinrecht, br. 3/1986, str. 154-156.:

Oko 21:30 sati gospođa W. više je puta udarila svog supruga čeličnom šipkom dok je spavao. Odmah nakon 22:00 sata oboje su dopremljeni u bolnicu kolima hitne pomoći. Liječnik hitne pomoći ubrizgao je gospođi W. sredstvo za smirenje. Poslije prvog prijema i tretmana u internoj ambulanti bolnice te dužeg razgovora sa sinovima pacijentice, liječnik neuropsihijatar pacijentici je postavio sljedeću dijagnozu: „Psihički: najprije stuporozna slika s naizmjeničnim reakcijama. Afektivno stanje promjenjivo, jedan trenutak plače, a drugi je sretna zbog onoga što je učinila. Nema sigurnih formalnih ili stvarnih smetnji u mišljenju, nema ničeg što bi ukazivalo na neposrednu opasnost od suicida. Sumnjiva dijagnoza: reakcije kratkog spoja, moguće psihotične epizode". Neuropsihijatar je smatrao da je pacijentici W. potrebno bolničko liječenje, ali u nedostatku slobodnih kreveta na neurološkom odjelu bolnice on ju je oko 00:30 sati smjestio u bolnički toalet. Radi smirenja propisao joj je Neurocil kapi te naredio noćnoj službi da na nju osobito pripazi. Tijekom iste noći kod pacijentice se nije dogodilo ništa što bi bilo vrijedno pažnje, a ujutro oko 6:00 sati, kad je izvršena smjena dežurnog osoblja, pacijentica je spavala. Oko 7:30 sati osoblje za njegu bolesnika zateklo je pacijenticu W. u očajnom stanju: umazanu izmetom i potpuno prljavu. Okupali su je i tom je prilikom kod nje nastupio kolaps u cirkulaciji krvotoka pa je zato ubrzo smještena na odjel za intenzivnu njegu. Navečer istoga dana kod pacijentice je utvrđena upala pluća prouzročena vjerojatno inhalacijom povraćenog uglja koji joj je dan zbog sumnje da je, u namjeri da izvrši samoubojstvo, uzela otrov. Navečer je pacijentica W. konačno priznala da je u kupaonici popila više gutljaja iz boce s otrovnim sredstvom za dezinfekciju. Nakon sedam dana umrla je od posljedica upale.

Predmet spora je tužbeni zahtjev supruga pacijentice W. kojim on tuži liječnika neuropsihijatra i bolnicu smatrajući ih odgovornima za smrt svoje supruge i zahtijeva od njih naknadu štete na ime uzdržavanja u obliku rente.

Sud prvog stupnja odbio je tužbeni zahtjev, Vrhovni zemaljski sud u Hammu potvrdio je prvostupanjsku presudu, a ni revizija upućena Saveznom vrhovnom sudu Njemačke nije imala uspjeha. Savezni vrhovni sud polazi od konstatacije da su tuženi liječnik i bolnica bili dužni, u okvirima potrebnih terapijskih mjera, učiniti sve kako bi spriječili samoubojstvo pacijentice izazvano njezinom bolešću. Međutim, po njegovom mišljenju nije dokazano da su tuženi postupili protivno svojim dužnostima. Nesumnjivo je da je pacijentica W. popila sredstvo za dezinfekciju u namjeri da izvrši samoubojstvo i da je uzimanje tog otrovnog sredstva objektivno bilo moguće spriječiti. Stalnim nadgledanjem ili smještanjem pacijentice u sigurnu sobu mogućnost samoubojstva bila bi znatno 
otežana, ako ne i potpuno isključena. Međutim, tuženi liječnik nije morao računati s neposrednom opasnošću od samoubojstva pacijentice; točnije rečeno, nije utvrđeno da se s time trebalo računati. Teret dokazivanja suprotnoga leži na tužitelju. Pacijentica W. je prije dolaska u bolnicu dva puta pokušala izvršiti samoubojstvo, ali tuženi liječnik to nije znao. Po mišljenju sudskog vještaka, čak i da je znao, to ne bi bilo dovoljno da se on ukori zbog propusta prilikom postavljanja dijagnoze i određivanja mjera nadzora nad pacijenticom jer su se navedeni pokušaji samoubojstva odigrali prije više od dvadeset godina, tako da se o njima nije moralo voditi računa pri ocjeni stanja pacijentice. Mišljenje je sudskoga vještaka da je tuženi liječnik ispravno ocijenio stanje pacijentice nakon razgovora s njom i njezinim sinovima. Bilo je dovoljno to što je liječnik dao pacijentici sredstvo za smirenje i naložio nadzor. Time je učinio ono što bi se od njega moglo očekivati. Savezni vrhovni sud drži da nisu postojale indicije koje bi ukazivale na opasnost od samoubojstva pa zato smatra da tuženi liječnik i bolničko osoblje nisu postupili protivno svojim obvezama kad su pacijenticu smjestili u kupaonicu u kojoj je stajalo otrovno sredstvo za dezinfekciju. Takve se stvari u domaćinstvima obično nalaze u kupaonicama, negdje po strani, pa je tako uobičajeno i u bolnicama. Sud je mišljenja da bi bilo pretjerano očekivati od bolnice da takvo sredstvo drži uvijek pod ključem. Miješanje dotične boce s medikamentima nije bilo moguće. U ovome slučaju ne postoji, dakle, povreda dužnosti pažljivog postupanja koja bi opravdala pravo na naknadu štete. Tuženi liječnik mogao je smatrati da je poduzeo dovoljne mjere kako bi pacijenticu zaštitio od samooštećenja jer joj je dao sredstvo za smirenje i naložio stalni nadzor. Činjenica da pacijentica tijekom noći nije učinila ništa neobično dokazuje da je takvo očekivanje bilo opravdano. Nije utvrđeno ni da je sljedećeg jutra, poslije buđenja, ispoljila iznimno stanje koje bi iziskivalo posebnu zaštitu od samoubojstva. Teret dokazivanja drukčijeg stanja stvari leži na tužitelju. On bi trebao dokazati da je takvo stanje tuženi liječnik mogao primijetiti i da bi ono, budući da je bilo navečer, potrajalo do sljedećeg jutra. Takav dokaz tužitelj nije u stanju pružiti jer nitko ne zna kakvo je bilo stanje pacijentice u trenutku uzimanja otrova. Sudski je vještak potvrdio da ni on ne bi smatrao da će dijagnosticirano stanje pacijentice koje je postojalo navečer potrajati do ujutro. Naprotiv, on drži da je situacija obrnuta: pacijentica je mogla popiti više gutljaja otrova pa čekati do večeri da nastupi djelovanje, samo zato što je imala čvrstu namjeru izvršiti samoubojstvo. U običnim bolnicama, jakoj i neshvatljivoj volji pacijenta da počinila samoubojstvo nije se moguće suprotstaviti nikakvim učinkovitim sredstvima. Stoga je i Savezni vrhovni sud ostao pri stavu prvostupanjskog i drugostupanjskog suda te odbio tužbeni zahtjev u cijelosti.

\section{GRA円ANSKOPRAVNA ODGOVORNOST ZBOG POVREDE MEDICINSKOG STANDARDA I KORELATIVNA EKONOMSKA PITANJA}

\subsection{Financijski učinci i trendovi odštetnopravne odgovornosti zbog liječničke pogreške}

Pravna i ekonomska literatura upozoravaju na rastući trend pokretanja odštetnopravnih postupaka radi popravljanja štete prouzročene liječničkim pogreškama. Per exemplum, podatci za SAD upućuju porast ukupnih posrednih i neposrednih troškova koji stoje u kauzalnoj vezi s povredom medicinskog standarda. Tako se registrira se porast troškova odvjetničkog zastupanja koji iznosi prosječno po slučaju 47.158,00 USD u 2010. godini što je porast od $62,7 \%$ od 2001. godine; tijekom 2010. čak je 63,7 \% postupaka pravomoćno okončano u korist tuženih liječnika/zdravstvenih ustanova. Pritom su troškovi odvjetnika branitelja iznosili u prosjeku 26.851,00 USD. Prosječni ostvareni odštetnopravni zahtjev iznosio je 
u 2010. g. 331.947,00 što je povećanje od 11,5\% od 2001. godine. Udjel polica osiguranja od profesionalne odgovornosti liječnika koje prekoračuju prekoračenje po štetnom događaju od jedan milijun dolara povećao se s $28 \%$ na $41 \%$ u istom razdoblju. ${ }^{59}$ Smatra se kako od 4 do18 \% pacijenata trpe posljedice liječničke nepažnje u obavljanju medicinskog tretmana sa brojnim štetnim posljedicama na zdravlje i ekonomsku sferu pacijenata, pritom tek manji broj štetnih događaja biva predmetom građanskopravnog postupka za naknadu štete. ${ }^{60}$ Neovisno o tome, financijski izdatci uvjetovani postupanjem liječnika contra legem artis izravno dovode do povećanja bolničkih rashoda u rasponu od 1.246,00 do 4.769,00 USD godišnje, ovisno o tipu zdravstvene ustanove i specifičnom medicinskom tretmanu koje se tamo provodi. Prema američkom Institute of Medicine ukupni godišnji izdatci po različitim osnovama, a koji su per directum et indirectum izazvani postupanjem liječnika i drugog zdravstvenog osoblja protivnom pravilima medicinske struke procjenjuju se na čak od 17 do 29 milijardi dolara godišnje! ${ }^{61}$

$\mathrm{S}$ istim se trendovima suočavaju u Italiji. Prema dostupnim podatcima, ${ }^{62}$ na godišnjoj se razini pokreće otprilike 15.000 odštetnopravnih postupaka zbog šteta prouzročene liječničkom pogreškom, a zdravstvene ustanove na ime odštetnine pacijentima isplaćuju kumulativni iznos od oko 10 milijardi eura. Relativno najveći postotak tužbenih zahtjeva tiče se liječničkih pogreški u okviru ortopedijske kirurgije i traumatologije, a bilježi se i relativno najveći broj pokrenutih kaznenih postupaka protiv liječnika i drugoga zdravstvenog osoblja na cijelom području EU-a. Referentna statistika ukazuju da liječnik s 20 godina prakse ima 80 \% šansi da će protiv njega biti pokrenut građanskopravni postupak zbog povrede pravila medicinske struke uz jednaki postotak vjerojatnosti od $80 \%$ da će predmetni postupak biti okončan u njegovu korist odbijanjem tužbenog zahtjeva. ${ }^{63}$

Recentno je istraživanje ${ }^{64}$ pokazalo kako je postupak naknade štete pokrenut u odnosu na 243 kirurga, pri čemu je utvrđena odgovornost u $75 \%$ slučajeva, od toga čak $61 \%$ iz područja elektivne ortopedske kirurgije. Kirurški su timovi tuženi u tek 30 slučajeva te je presuđena građanskopravna odgovornost i određena naknada štete u 22 sporna slučaja. Ukupno dosuđeni iznos na ime popravljanja štete iznosio je 12.350.000,00 eura. Kada su u pitanju štetne posljedice sa smrtnim ishodom sudovi razlikuju hitne i elektivne kirurgije, tako da odštetu dosuđuju u prosječnom iznosu od 896.989,00 eura, kad je u pitanju elektivna kirurgija u odnosu na EUR 297.921,00 kad je smrt pacijenta prouzročena hitnim kirurškim zahvatom (traumatologija). Statistike pokazuju da je europsko javno mnijenje postalo svjesno da postoje konkretne i realne opcije koje omogućuju učinkovito ostvarenje prava na naknadu štete u tim

59 Lewis, M. Jr., Medical malpractice costs continue to climb, Medical Economics, 11. Jan. 2012, str. 1-2, <https://www.medicaleconomics.com/articles/medical-malpractice-costs-continueclimb\%20>, 5. ožujka 2019.

60 Arlen, J., Economic Analysis of Medical Malpractice Liability and its Reform, op. cit.

61 loc. cit.

62 Traina, F., op. cit., str. 1.

63 Fattorini, P. i dr., Casistica ortopedica dell' osservatorio GISDI, Medical malpractice daily. Supplemento di Medicina Legale Quaderni Camerti, reg. Trib. Di Camerino, 2007.

64 Tarantino, U. i dr., op. cit, str. 1-10. 
slučajevima. Pritom je fenomen zabilježio proporcionalno povećanje troškova za naknadu štete zbog povrede medicinskoga tretmana, koji su ukupno porasli za oko 200 \% prema Europskom bolničkom i zdravstvenom savezu te variraju između 9 i 15 eura per capita. ${ }^{65}$

U pogledu financijskih učinaka odštetnopravne odgovornosti na poslovanje zdravstvenih ustanova u Hrvatskoj bilo je potrebno analizirati dostupno izvješće HZZO-a za odgovarajuće izvještajno razdoblje ${ }^{66}$ koje je pokazalo da ukupni

65 European Hospital and Healthcare Federation.

66 Tako su na poziciji rashoda evidentirani ostali rashodi - naknade štete, međutim proučavanjem izvješća utvrđeno je kako se odnosni rashod u iznosu od oko 24 milijuna kuna odnosi na štete od profesionalnih oboljenja te da izdatci na ime naknade pacijentima na temelju pravomoćno dosuđene odštete nisu zabilježeni. Najveći je dio rashoda - izdataka utrošeno za zdravstvenu zaštitu, koja iznosi 20.101.295.820 kn i čini 88,37 \% sveukupnih izdataka. Za naknade je utrošeno 9,91 \% izdataka, a svi ostali izdatci čine 1,72 \% ukupnih izdataka. U obveznom zdravstvenom osiguranju izdatci za zdravstvenu zaštitu iznose 18.829.544.568 kn i manji su od istih izdataka prethodne godine, kada su izdtaci za zdravstvenu zaštitu iznosili 19.128.774.868 kn. Međutim, napominje se da su u izdatcima 2014.godine iskazana i sredstva sanacije zdravstvenih ustanova u iznosu od 1.951.368.099 kn, te umanjimo li za taj iznos, tada izdatci za zdravstvenu zaštitu za 2014.godinu iznose 17.177.406.769 kn, iz čega slijedi da su izdatci za zdravstvenu zaštitu u 2015.godinu veći za 9,62\%. U dopunskom zdravstvenom osiguranju izdatci za zdravstvenu zaštitu iznose 1.193.163.396 kn. Izdatci za zdravstvenu zaštitu za ozljede na radu i profesionalne bolesti iznose $78.587 .856 \mathrm{kn}$, a u prethodnoj godini su iznosili $74.796 .168 \mathrm{kn}$. Ukupne naknade od siječanj doprosinca 2015. godine iznose $2.252 .826 .457 \mathrm{kn}$ i čine $9,91 \%$ ukupnih izdataka i veće su od istih izdataka u 2014. godini za 3,42\%. Ukupne naknade u prethodnoj godini su iznosile 2.178.295.339 kn. Zdravstvena zaštita i naknade čine 98,28 \% ukupnih izdataka. Ostale izdatke čine rashodi za zaposlene, materijalni izdatci, financijski izdatci, rashodi za nabavu nefinancijske imovine i izdatci za financijsku imovinu i otplatu zajma, koji u 2015. godini iznose $392.056 .573 \mathrm{kn}$, manji su od ostalih izdataka prethodne godine, kada su iznosili $398.916 .490 \mathrm{kn}$ i čine $1,72 \%$ sveukupnih izdataka. U 2015. godini rashodi su za zaposlene iznosili 228.335.271 kn i manji su za $0,97 \%$ od rashoda prethodne godine, kada su iznosili $230.561 .633 \mathrm{kn}$, a čine ih bruto plaće s doprinosima na plaće, jubilarne nagrade, dar za djecu zaposlenika, otpremnine radi odlaska u mirovinu, naknade zbog bolesti zaposlenika, a sve u skladu s Kolektivnim ugovorom za djelatnosti zdravstva i zdravstvenog osiguranja. Osnovica za obračun plaće u 2014. i u 2015. godini iznosi 5.108,84 kn. Prosječan broj zaposlenih na osnovi sati rada u HZZO-u u 2015. godini je 2.167 zaposlenika za koje su sredstva za bruto plaću na godišnjoj razini iznosila $190.321 .811 \mathrm{kn}$. Iz toga proizlazi da prosječna mjesečna bruto plaća po zaposlenom iznosi $7.318,94$ kn. Prema podatcima Državnog zavoda za statistiku prosječna bruto plaća po zaposlenom u pravnim osobama Republike Hrvatske za razdoblje siječanjprosinac 2015. godini iznosi 8055,00 kn. Prema kadrovskoj evidenciji stvarni broj zaposlenih u HZZO-u, 1. siječnja 2015. godine bio je 2.295 zaposlenika, a 31. prosinca 2015. godine je 2.306 zaposlenika, što je za 11 zaposlenika više. U HZZO-u je 31. prosinca 2015. godine evidentirano službenika dužnosnika i sadržani su u ukupnom broju zaposlenika. U promatranom razdoblju materijalni izdatci su iznosili $97.500 .958 \mathrm{kn}$ i manji su od istih izdataka prethodne godine kada su iznosili $128.947 .932 \mathrm{kn}$. Sagledamo li materijalne izdatke po vrstama, može se zaključiti da je najveće smanjenje zabilježeno na stavci Ostali nespomenuti rashodi poslovanja, koji su u 2014. godini iznosili $28.975 .691 \mathrm{kn}$, a u promatranom razdoblju iznose $81.434 \mathrm{kn}$. Najveći je dio tih rashoda u prethodnoj godini iskazano u dopunskom zdravstvenom osiguranju, a odnosi se na ispravak vrijednosti potraživanja. Smanjena je i stavka Naknade za prijevoz s $12.177 .599 \mathrm{kn}$ u 2014. na 9.949.496 kn u 2015. godini zbog promjene načina obračuna prijevoza. Rashodi za uredski materijal i ostali materijalni rashodi smanjeni su sa 7.082.879 kn u 2014. na 4.966.837 
neprepoznati izdatci na ime naknade štete zbog liječničke pogreške ne terete bitno proračun HZZO te se stoga uopće posebno ne evidentiraju! Razvidno je da hrvatski zdravstveni sustav za razliku od analiziranih (Italija, SAD i dr.), nije opterećen velikim troškovima za popravljanje štete zbog povrede medicinskog standarda te da hrvatska pravna praksa nije usklađena s praksom u referentnim državama koje smo komparativno obradili. Ipak, moglo bi se predvidjeti da će uključenje Hrvatske u ekonomski i pravni prostor EU-a sa vremenom utjecati na prihvaćanje prisutnog trenda pojačanog iniciranja odštetnih postupaka radi liječničke pogreške u provedbi medicinskog tretmana. Osim toga, građanskopravna odgovornost za povredu medicinskoga standarda može biti unosan posao koji omogućuje prihode znatno širem krugu subjekata od oštećenika-pacijenata, što dobro ilustrira situacija u SAD-u i Italiji.

\subsection{Pravno-ekonomski model optimalne zdravstvene skrbi}

\subsubsection{Uvodne napomene}

Općenito se smatra kako odštetnopravni sustav poticajno djeluje u smislu poboljšanja medicinske usluge, odnosno, ideja da potencijalni štetnik treba obeštetiti svoju žrtvu (oštećenika) trebala bi imati preventivni učinak. ${ }^{67} \mathrm{U}$ tom smislu, pravna $\mathrm{i}$ ekonomska teorija postavljaju pitanje kako bi pristup ex post mogao povratno poticajno utjecati na način da pro futuro prevenira povredu medicinskog tretmana. Jedan od začetnika problematike, Guido Calabresi s pravnog odsjeka Sveučilišta Yale, ${ }^{68} \mathrm{u}$ svom poznatom djelu ,Troškovi nezgode“ razlikuje primarne, sekundarne i tercijarne troškove. Pritom primarni troškovi nastaju izbjegavanjem nastanka štete koja bi se uopće mogla pojaviti; sekundarni troškovi odnose se na ravnomjerno raspoređivanje financijskih gubitaka, dok se tercijarni troškovi odnose na rashode administracije u

kn u 2015. godini. Smanjeni su i izdatci za Usluge telefona, pošte i prijevoza s 21.529.226 kn u 2014. na 18.197.365 kn u 2015. godini. Zakupnine i najamnine su povećane, u 2015. godini iznose $18.696 .093 \mathrm{kn}$, a u prethodnoj su godini iznosile 16.409.231 kn. Komunalne i računalne usluge su također povećane. Financijski izdatci su povećani, jer izlaskom iz riznice usluge platnog prometa plaćaju se drukčije i iznose $21.403 .334 \mathrm{kn}$, a čine ih izdatci platnog prometa i bankarske usluge, negativne tečajne razlike te zatezne kamate (u 2014. su iznosili 3.530 .887 kn). Izlaskom iz sustava Državne riznice HZZO je obvezan plaćati bankarske usluge. Ostali izdatci iznose $24.197 .050 \mathrm{kn}$ i odnose se na isplatu odštetnih zahtjeva radnika oboljelih od profesionalne bolesti zbog izloženosti azbestu. U 2014. godini ostali su izdatci iznosili 9.439.231 kn. Rashodi za nabavu nefinancijske imovine iskazani su u iznosu od $14.231 .095 \mathrm{kn}$, manji su od istih izdataka iskazanih u 2014. godini, kada su iznosili $20.279 .063 \mathrm{kn}$. U strukturi ulaganja najvažniji su rashodi za uredsku opremu i namještaj 52,58 \% (nabava uredskog namještaja i opreme te nabava informatičke opreme). Ulaganja u računalne programe čine $5,91 \%$ rashoda. Na dodatna ulaganja na građevinskim objektima utrošeno je 39,70\% sredstava (izrada projektne dokumentacije te adaptacija i uređenje prostora, ponajprije područne službe Varaždin, Dubrovnik i Šibenik). Izdatci za financijsku imovinu i otplata zajma iznose 6.001.041 kn, a čine ih izdatci za otplatu informatičke opreme koja je kupljena na obročnu otplatu.

67 Usp. Schiemann, G., Argumente und Prinzipien bei der Fortbildung des Schadensrechts, München, Beck, 1981., str. 185.

68 Calabresi, G., The Costs of Accidents: A Legal and Economic Analysis, New Haven/London, Yale University Press, 1970. 
okviru određenoga pravnog sustava povezani s postupkom naknade štete. Pravna teorija zauzima gledište prema kojem bi odštetnopravni sustav u svom totalitetu, kao zaseban mehanizam u okviru sustava zdravstvene skrbi, trebao dati poticaj da se umanji totalni društveni trošak zbog nezgoda, odnosno, trebalo bi stvarati pravnoekonomski sustav koji bi trebao minimalizirati ukupni trošak koji stoji u kauzalnoj vezi s nastupom štetnih događaja (nezgoda). ${ }^{69}$

\subsubsection{Klasični model nezgoda}

U daljnjoj razradi tematike razmatrani su modaliteti optimalne zaštite prava pacijenata povezani s konkretnim pravilima civilnopravne odgovornosti. Istraživanje je ponajprije uputilo na klasični model nezgoda (šteta) koji preispituje ulogu odštetnog prava i profesionalne odgovornosti te ga dovodi u vezu s ukupnim društvenim boljitkom koji ovisi o tome koliko je svaki pojedini pružatelj zdravstvene usluge (liječnik) uložio u medicinsku obradu svakog pojedinog pacijenta. Klasični model nezgoda (šteta) ističe ulogu građanskopravne odgovornosti za štetu zbog povrede medicinskog standarda, jer se smatra da navedeni pravni institut djeluje tako što inter alia osnažuje opću društvenu korist, budući da bi u nedostatku takve pravne odgovornosti, zdravstvene ustanove i liječnici, prirodno težili smanjenju vlastitih financijskih ulaganja na ime troškova medicinskog tretmana, a što bi dovelo do pada očekivane razine zdravstvene usluge koju su obvezatni pružiti. ${ }^{70}$ Ukazuje se zakonitost prema kojoj djelotvoran odštetnopravni sustav ima učinak generalne prevencije od nastupa štetnih događaja, odnosno, djeluje ex ante, što implicitno presumira viši prosječan stupanj ispoljene stručnosti u provođenju svakodnevnih medicinskih tretmana. ${ }^{71}$

Posebno se istraživala individualna odluka institucionalnih pružatelja zdravstvenih usluga u smjeru financijskog ulaganja u konkretan medicinski tretman koja je, u nedostatku djelatnog pravno-zaštitnog mehanizma, realna pretpostavka sistemski nepovoljnog utjecaja na razinu kvalitete medicinskog tretmana. Naime, podrazumijeva se situacija prema kojoj trošak obavljanja odabranoga medicinskog tretmana uvijek i isključivo pada na teret institucionalnog pružatelja zdravstvene usluge, kojemu su za razliku od pacijenta poznata pravila medicinske struke koja omogućuju pružanje optimalne profesionalne usluge. U tim bi se okolnostima moglo razumno pretpostaviti da bi, u nedostatku sustava odštetnopravne odgovornosti kao svojevrsnog "osigurača kvalitete", bilo realno za očekivati da bi zdravstvene ustanove $\mathrm{u}$ nemaloj mjeri faktično provodile tek suboptimalni medicinski tretman koji u potpunosti ne odgovara zahtijevanom medicinskom standardu, budući u cijelosti i samostalno snose trošak liječenja, dok istodobno ne ostvaruju maksimalnu ekonomsku korist od ulaganja u spomenuti optimalan medicinski tretman. Ta bi se anomalija inter alia mogla učinkovito otkloniti interpolacijom sustava zdravstvenog osiguranja jer $\mathrm{u}$ tom slučaju trošak zdravstvene usluge prelazi sa liječnika na osiguratelja. ${ }^{72}$

69 Faure, M., op. cit., str. 7.

70 Arlen, J., Economic Analysis of Medical Malpractice Liability and its Reform, op. cit., str. 34.

71 Vojković, H., Ekonomski učinkovita zdravstvena skrb i liječnička pogreška, Zagreb, Ekonomski pregled, 2019., str. 18 (u objavljivanju).

72 Danzon, P. M., Tort Liability: A Minefield for Managed Care?, Chicago, The Journal of Legal 
Stajališteje Pravne literature da bi se preventivno smanjenje učestalosti liječničkih pogreški moglo postići trajnim ulaganjem u sigurnost pacijenta ${ }^{73}$ koje uključuje stalno stručno usavršavanje, ulaganje u suvremenu medicinsku tehnologiju i sl. Time bi se ex ante ultimativno utjecalo na prosječno viši stupanj primijenjenoga standarda medicinske usluge. Takav bi modus operandi bitno umanjio opći rizik od pojave nestručnoga medicinskog tretmana s pratećim štetnim posljedicama - zdravstvenim, pravnim, ekonomskim, dok bi specifični rizik provođenja tretmana u odnosu na određenog pacijenta i dalje postojao. U uvjetima kad bi došlo do ostvarivanja takvog specifičnog rizika zbog poduzimanja medicinskog tretmana koji nema obilježje in optima forma et bonus pater familias, slučaj bi se dalje pravno i ekonomski rješavao sukladno pravilima pravnog instituta građanskopravne odgovornosti.

\subsubsection{Optimalni standard zdravstvene skrbi}

Prema osnovnom pravno-ekonomskom modelu odštetnopravni sustav je u funkciji utvrđivanja ekonomski učinkovitog rješenja jer se temeljni ratio instituta građanskopravne odgovornosti očituje u dvostrukom smislu. S jedne strane, očituje se u smanjenju troškova ostvarenog štetnog događaja - troškovi štete. S druge strane očituje se u smanjenju troškova koji nastaju u procesu prevencije štete preventivni troškovi. ${ }^{74}$ Razvidno je da u okolnostima izostanka funkcionalnog sustava građanskopravne odgovornosti, štetnik ne bi imao ekonomsko-pravni poticaj postupati s dužnom profesionalnom pozornosti budući da prouzrokovanje štete ne bi pogađalo njegovu ekonomsku sferu. Nastavno na to shvaćanje, teorija je prihvatila pravila dužne pažnje (neglicence rule) kao esencijalnu komponentu instituta građanskopravne odgovornosti, a koja pravila izravno potiču potencijalnog štetnika da postupa lege artis radi ostvarenja učinkovite razine dužne skrbi. Implementacija pravila dužne pažnje, odnosno, odštetnopravni sustav sa svojim pravnim i ekonomskim implikacijama, posljedično dovode do toga da potencijalni štetnik pruža uslugu u režimu standarda optimalne skrbi jer pravni sustav profesionalni standard medicinskog postupanja izjednačuje upravo s ekonomskom konstrukcijom optimalne skrbi za primatelja usluge - hipotetičkog oštećenika. ${ }^{75}$ Kako je optimalan standard zdravstvene skrbi određen kao takva razina skrbi gdje su granični troškovi skrbi jednaki graničnim koristima po osnovi smanjenja rizika od nastanka štete, nepridržavanje tako determiniranog standarda optimalne skrbi, potencijalni štetnik neće imati ekonomski interes, jer bi u neželjenoj situaciji ostvarenja rizika od nastanka štete povećao svoje ukupne troškove. Mora se naglasiti da izneseni modalitet primjene pravila dužne pažnje u praksi ostvaruje povoljne ekonomske učinke isključivo uz uvjet da pravni sustav jasno određuje pravno zahtijevanu razinu skrbi - pravni standard dužne pažnje liječnika - kao adekvatnu ekonomski definiranom modelu optimalne zdravstvene

Studies, vol. 26, 2/1997, str. 491-519.

73 Arlen, J., Economic Analysis of Medical Malpractice Liability and its Reform, op. cit., str. 39.

74 Calabresi, G., The Costs, str. 17.

75 Shavell, S., Economic Analysis of Accident Law, Cambridge, Mass., Harvard University Press, 1987., str. 1-25; Calabresi, G., Optimal Deterrence and Accidents, New Haven, Yale Law Journal, vol. 84, 4/1975, str. 658. 
skrbi. ${ }^{76}$ Iz navedenoga proizlazi zaključak o postojanju odnosa interdependentiae ekonomskog, pravnog i zdravstvenog sustava, a dodirna točka ovih sustava, određena je definicijom optimalnoga profesionalnog standarda zdravstvene skrbi. ${ }^{77}$ Naime, uzajamnost, međuovisnost i kauzalitet jasno dolaze do izražaja u situaciji kada se dosljedno primjenjuju pravila dužne pažnje (neglicence rule) u okviru provođenja medicinskog tretmana.

$\mathrm{U}$ razradi koncepta optimalnoga profesionalnog standarda zdravstvene skrbi odabrana je metodologija klasične cost/benefit analize kako bi se odredila ona konkretna razina zdravstvene skrbi koja u konačnici vodi do minimaliziranja ukupnih društvenih troškova koji rezultiraju povredom medicinskog standarda postupanja i korelativnom štetom koju oštećenik trpi kao posljedicu. ${ }^{78}$ Općeprihvaćeno je stajalište da bi već mogućnost primjene pravila građanskopravne odgovornosti, koja djeluju ex post u uvjetima nastale štete, trebala izazvati adekvatnu reakciju subjekata već ex ante kako bi se primijenila odgovarajuća profesionalna pozornost ili korigirale aktivnosti u smjeru smanjenja rizika od nastupa štetnog događaja.

\subsubsection{Posebno o optimalnom standardu zdravstvene skrbi u Hrvatskoj}

Definicija standarda optimalne skrbi u hrvatskom pravnom, medicinskom i ekonomskom poretku polazi od načelnih odredbi koje uređuju područje zdravstva te kojima se utvrđuje model ostvarivanja kvalitete zdravstvene zaštite koji se zasniva na načelu učinkovitosti $i$ djelotvornosti sustava kvalitete zdravstvene zaštite $i$ sigurnosti zdravstvenih postupaka, a što se ostvaruje provedbom mjera za osiguranje kvalitete zdravstvene zaštite. Također, hrvatski pravni poredak ustanovljava načelo sigurnosti pacijenata koje se ostvaruje provedbom mjera kojima se svakom pacijentu osigurava pravo na kvalitetnu zdravstvenu zaštitu sukladno njegovu zdravstvenom stanju i općeprihvaćenim stručnim standardima te kojima se sprječavaju štetni neželjeni događaji čija bi posljedica mogla biti smrt ili oštećenje zdravlja pacijenta. Sustavom mjera koje se provode nastoji se postići optimalan odnos između učinaka provedenih zdravstvenih postupaka i troškova nastalih njihovom provedbom, pritom uvažavajući tehničke, organizacijske i gospodarske čimbenike. Sukladno zasadama klasičnog modela nezgoda (šteta), ${ }^{79}$ hrvatski zdravstveni model ulogu odštetnog prava i građanskopravne strukovne odgovornosti liječnika dovodi u vezu s ukupnim društvenim boljitkom, a u skladu s ustavnom vrednotom - pravo na zdravstvenu zaštitu. ${ }^{80}$ Kako je opširnije elaborirano u prethodnim poglavljima, u hrvatskoj praksi od liječnika se očekuje da pri obavljanju medicinske usluge postupa s pažnjom dobrog stručnjaka (gospodarstvenika), odnosno da postupa s povećanom pažnjom, prema pravilima struke i običajima profesije ${ }^{81}$ Prema tomu, hrvatsko pozitivno pravo od

76 Vojković, H., Ekonomski, str. 16.

77 ibid., str. 15.

78 Shavell, S., op. cit., str. 7.

79 Arlen, J., Economic Analysis of Medical Malpractice Liability and its Reform, op. cit., str. 34.

80 Čl. 59. Ustava Republike Hrvatske, NN, br. 41/2001 (pročišćeni tekst), 55/2001, 76/2010, $85 / 2010,05 / 2014$.

81 Čl. 18. st. 2. Zakona o obveznim odnosima. 
medicinskog djelatnika traži da postupa prema standardu dobrog, a ne tek prosječnog stručnjaka. Povredu tako nametnutoga profesionalnog standarda određuje kao štetnu radnju s obilježjem protupravnosti u subjektivnom smislu, uz pretpostavku nastanka pravno relevantne štete. Liječnicima se izrijekom nameće obveza da u provođenju medicinskog tretmana postupaju prema pravilima zdravstvene struke, tako da svojim postupcima ne ugroze život i zdravlje ljudi ${ }^{82}$ te da promiču dostojanstveno i odgovorno profesionalno ponašanje poštivanjem propisa, pravila struke i kodeksa medicinske etike i deontologije. ${ }^{83}$

Slijedom iznesenoga može se zaključiti kako su u normativnom i teorijskom smislu hrvatsko odštetno i medicinsko pravo ipso facto inkorporali suvremene tekovine pravne i ekonomske misli u odnosu na predmetnu problematiku, premda postoji nemala diskrepancija u pogledu praktičnih učinaka usporedno s iskustvima zemalja koje smo analizirali. Neovisno o aktualnom hrvatskom iskustvu, može se općenito zaključiti kako bi, ex hypothesi, iz skladne implementacije sistemskih mjera koje se izvode iz gore navedenih načela, proizišao upravo onaj željeni optimalan odnos između rezultata obavljenih medicinskih tretmana i troškova nastalih njihovom provedbom, a na čemu inzistira ekonomska znanstvena misao.

\section{ZAKLJUČNE NAPOMENE}

Nužno je istaknuti kako je provedena analiza pravnih i ekonomskih učinaka instituta građanskopravne odgovornosti zbog liječničke pogreške, ukazala da hrvatski propisi prihvaćaju načelo učinkovitosti i djelotvornosti sustava kvalitete zdravstvene zaštite te sigurnosti zdravstvenih postupaka. Navedena su načela teorijski i normativni supstrat u odnosu na klasični model nezgoda (šteta) čime je hrvatsko pozitivno pravo uključilo suvremene tekovine pravne (posredno i ekonomske misli), usprkos očitom raskoraku u pogledu praktičnih učinaka u usporedbi s pravnim poredcima većine starijih država članica EUa i SAD. Istraživanje je potvrdilo nedvojbenu činjenicu da je već i mogućnost ostvarenja odštetnopravnog zahtjeva u slučaju građanskopravne odgovornosti za liječničku pogrešku per se sustavni poticaj in continuo procesu profesionalizacije zdravstvene usluge. Time pravni poredak posljedično utječe na standard kvalitete zdravstvene skrbi s ultimativnim učinkom prevencije neželjenih posljedica nestručnih medicinskih zahvata. U tom se smislu otkriva zakonitost prema kojoj djelotvorni odštetnopravni sustav ima učinak generalne prevencije od nastupa štetnih događaja, te djeluje ex ante, čime se iskazuje viši prosječan stupanj ispoljene stručnosti u provođenju svakodnevnih medicinskih tretmana. ${ }^{84}$

U slučaju povrede medicinskog standarda oštećenik će u pokrenutom parničnom postupku morati dokazati postojanje pravno relevantne štete koja je u uzročno-posljedičnoj vezi s poduzetim medicinskim tretmanom, ali neće morati dokazivati subjektivni element krivnje jer se ona presumira. Tipičan je modus povrede medicinskog standarda liječnička pogreška koja se neovisno o tipološkim

82 Čl. 124. st. 3. Zakona o zdravstvenoj zaštiti.

83 Čl. 2. st. 2. t. 5. Zakona o liječništvu, NN, br. 121/03, 117/08.

84 Vojković, H., Ekonomski, str. 18. 
karakteristikama očituje, in genere, u postupanju liječnika, protivno pravilima zdravstvene struke te njenim moralnim i etičkim načelima, odnosno kao postupanje u neskladu s provjerenim standardima suvremene medicinske znanosti, a što je rezultiralo povredom pacijentova zdravlja ili života, tj. povredom prava osobnosti. ${ }^{85}$ Središnje je pravno pitanje karakterističnog spora zbog liječničke pogreške problematika medicinskog standarda, a o čemu sud oblikuje stajalište osloncem na nalaz i mišljenje vještaka medicinske struke koji će odrediti aktualni standard medicinskog postupanja. Međutim, neovisno o vještačkom nalazu i mišljenju koje je u odštetnopravnoj parnici često ključno, vještakova uloga nije odlučujuća ako je u pitanju pravna ocjena eventualne liječnikove nepažnje. ${ }^{86}$ Utvrđivanje liječničke pogreške sud će razmatrati kroz prizmu ponašanja liječnika u okviru medicinskog tretmana in concreto pri čemu mjerilo ponašanja neće biti neka prosječno pametna i pažljiva osoba, nego uobičajeno pažljiv doktor sukladno prosječnom standardu koji vrijedi za liječnike - bonus pater familias standard. ${ }^{87}$ Naime, u odnosu na imperativ ostvarivanja medicinskog standarda in praxi, hrvatsko pozitivno pravo te pravna uređenja ad comparandum, ustanovljuju temeljne obveza liječnika u obavljanju medicinskog tretmana, te napose propisuju dužnost postupanja s povećanom pažnjom, prema pravilima struke i običajima-pažnja dobrog stručnjaka.$^{88}$ Kako se zdravstvena djelatnost u Republici Hrvatskoj ostvaruje u različitim organizacijskim formama (zdravstvene ustanove, trgovačka društva koja obavljaju zdravstvenu djelatnost, privatni zdravstveni radnici), kao relevantan pravni standard uzima se pažnja dobrog gospodarstvenika i dobrog stručnjaka ${ }^{89}$ Pridržavanje navedenoga standarda minimizira rizik od suboptimalnog tretmana koji bi bio suprotan pravilima medicinske profesije - contra legis artis, a čime se preventivno harmoniziraju pravna, medicinska te ekonomska komponenta. Naime, u radu su posebno istražena komplementarna ekonomska pitanja, odnosno, sinergijski učinak pravnog i ekonomskog sustava. Tako se utvrdilo da građanskopravna odgovornost za liječničku pogrešku de facto djeluje kao svojevrsni „,protektor“ medicinskog standarda koji svojim pravnim i ekonomskim posljedicama per consequens oblikuje zdravstveni proces tako što potiče potencijalnog štetnika (liječnik/zdravstvena ustanova) u smjeru pružanja zdravstvene uslugu u režimu standarda optimalne skrbi, imajući na umu da upravo odštetnopravni sustav navedeni standard medicinskog postupanja izjednačuje s ekonomskom kategorijom optimalne skrbi za pacijenta. ${ }^{90}$

Analizirajući opći determinacijski okvir pojma optimalnoga profesionalnog standarda zdravstvene skrbi, kako ga shvaća suvremena pravna, medicinska i ekonomska znanost, važno je uočiti da se pod rečenim pojmom podrazumijeva utvrđena razina zdravstvene skrbi koja ultimativno rezultira u smanjenju ukupnih društvenih troškova zbog povrede medicinskog standarda postupanja, kao i štetom koju oštećenik trpi. ${ }^{91}$ Sukladno tomu, primjena pravila dužne pažnje (engl.

85 ibid., str. 140.

86 loc. cit.

87 Faure, M., op. cit., str. 19.

88 Čl. 18. st. 2. ZOO-a.

89 Čl. 10. st. 1. i 2. ZOO-a.

90 Shavell, S., op. cit., str. 1-25; Calabresi, G., Optimal, str. 658.

91 Shavell, S., op. cit., str. 7. 
neglicence rule), odnosno, odštetnopravni sustav sa svojim pravnim i ekonomskim implikacijama in ultima linea dovodi do toga da mogući štetnik (liječnik/zdravstvena ustanova) medicinsku uslugu obavlja u režimu standarda optimalne skrbi, budući da pravni sustav navedeni standard medicinskog postupanja izjednačuje sa ekonomskom kategorijom optimalne skrbi za pacijenta. Slijedom iznesenoga može se zaključiti da učinkovita provedba/primjena pravila građanskopravne odgovornosti zbog povrede medicinskog standarda, a koja djeluje ex post u uvjetima nastale štete, redovito uzrokuje adekvatnu reakciju liječnika i drugoga medicinskog osoblja već ex ante u smjeru primjene zahtijevanog stupnja dužne profesionalne pažnje u aplikaciji odnosnog dijagnostičkog/terapeutskog postupka.

\section{Knjige i članci}

\section{LITERATURA}

1. Arlen, Jennifer, Contracting over Liability: Medical Malpractice and the Cost of Choice, Philadelphia, University of Pennsylvania Law Review, vol. 158, 4/2010, str. 957-1024.

2. Bevanda, Marko, Ugovor između liječnika i pacijenta, Rijeka, Zbornik Pravnog fakulteta Sveučilišta u Rijeci, vol. 26, 1/2005, str. 307-338.

3. Budak, Jelena, Ocjena pacijenata o kvaliteti rada zdravstvenog osoblja, u: Vehovec, Maja (ur.), O zdravstvu iz ekonomske perspektive, Zagreb, Ekonomski institut, 2014., str. 271282.

4. Calabresi, Guido, Optimal Deterrence and Accidents, New Haven, Yale Law Journal, vol. 84, 4/1975, str. 656-671.

5. Calabresi, Guido, The Costs of Accidents: A Legal and Economic Analysis, New Haven/ London, Yale University Press, 1970., str. 636-648.

6. Danzon, Patricia M., Tort Liability: A Minefield for Managed Care?, Chicago, The Journal of Legal Studies, vol. 26, 2/1997, str. 491-519.

7. Dettmeyer, Reinhard, Madea, Burkhard, Haftpflicht und Behandlungsfehler, u: Madea, Burkhard (ur.), Praxis Rechtsmedizin, 2. izd., Berlin/Heidelberg, Springer, 2007.

8. Deutsch, Erwin, Medizinrecht, 4. Aufl., Berlin, Springer, 1999.

9. Dika, Mihajlo, Rješavanje sporova za naknadu štete zbog liječničke greške, Skup Medicinski, pravni i ekonomski pogledi na profesionalnu odgovornost u zdravstvu i osiguranje od odgovornosti, Šibenik, Udruga poslodavaca u zdravstvu, 2007. (predavanje).

10. Fattorini, Paolo, Peretti, A., Bergamini, P, Valentini, Roberto, Casistica ortopedica dell' osservatorio GISDI, Medical malpractice daily. Supplemento di Medicina Legale Quaderni Camerti, reg. Trib. Di Camerino, 2007.

11. Faure, Michael, Economic observations concerning optimal prevention and compensation of damage caused by medical malpractice, u: Dute, Jos; Faure, Michael G., Koziol, Helmut (ur.), No-fault compensation in the health care sector, Wien/New York, Springer, 2004.

12. Ferrara, Santo Davide, Boscolo-Berto Rafael, Viel, Guido (ur.), Malpractice and Medical Liability, Berlin/Heidelberg, Springer, 2013.

13. Giesen, Dieter, International medical malpractice law: a comparative law study of civil liability arising from medical care, Tübingen/Dordrecht,Boston/London, Mohr/Nijhoff, 1988.

14. Gnjidić, Živko, Vještačenje profesionalne odgovornosti. Skup Medicinski, pravni i ekonomski pogledi na profesionalnu odgovornost u zdravstvu i osiguranje od odgovornosti, Šibenik, Udruga poslodavaca u zdravstvu, 2007. (predavanje)

15. Klarić, Petar, Odgovornost zdravstvene ustanove i zdravstvenih djelatnika za štetu, Zagreb, Hrvatska pravna revija, vol. 1, 8/2001. 
16. Koziol, Helmut, Österreichisches Haftpflichtrecht, Band II, Besonder Teil, Wien, Jan Sramek Verlag, 1984.

17. Kullmann, Hans Josef, Übereinstimmungen und Unterschiede im medizinischen, haftungsrechtlichen und sozialversicherungsrechtlichen Begriff des medizinischen Standards, Versicherungsrecht, 13/1997.

18. Laufs, Adolf, Uhlenbruck, Wilhelm, Handbuch des Arztrechts, 3. Aufl., München, Beck, 2002

19. Nikšić, Saša, Ugovor o zdravstvenoj usluzi, doktorska disertacija, Zagreb, Pravni fakultet, 2007.

20. Petrić, Silvija, Građanskopravna odgovornost zdravstvenih djelatnika, Rijeka, Zbornik Pravnog fakulteta Sveučilišta u Rijeci, vol. 26, 1/2005, str. 81-142.

21. Radišić, Jakov, Odgovornost zbog štete izazvane lekarskom greškom u lečenju i u obaveštavanju pacijenta, Beograd, Nomos, 2007.

22. Schiemann, Gottfried, Argumente und Prinzipien bei der Fortbildung des Schadensrechts, München, Beck, 1981.

23. Shavell, Steven, Economic Analysis of Accident Law, Cambridge, Mass., Harvard University Press, 1987.

24. Škavić, Josip, Zečević, Dušan, Komplikacija i greška - sudskomedicinski pristup, u: Građanskopravna odgovornost u medicini: okrugli stol održan 27. 2. 2008. u HAZU (ur. Barbić, Jakša), Zagreb, HAZU, 2008.

25. Tarantino, Umberto, Giai Via, Alessio, Macri, Ernesto, Eramo, Alessandro, Marino, Valeria, Marsella, Luigi Tonino, Profesional Liability in Orthopaedics and Traumatology in Italy, Philadelphia, Clinical Orthopaedics and Related Research, vol. 471, 10/2013, str. 3349-3357.

26. Traina, Francesco, Medical Malpractice: Experience in Italy, Philadelphia, Clinical Orthopaedics and Related Research, vol. 467, 2/2009, str. 434-442.

27. Vojković, Hrvoje, Ekonomski učinkovita zdravstvena skrb i liječnička pogreška, Zagreb, Ekonomski pregled (u objavljivanju).

28. Vojković, Hrvoje, Građanskopravna odgovornost za liječničku pogrešku, doktorska disertacija, Zagreb, Pravni fakultet, 2013.

\section{Pravni izvori}

29. Ustav Republike Hrvatske, NN, br. 41/01 (pročišćeni tekst), 55/01, 76/10, 85/10, 05/14.

1. Zakon o kvaliteti zdravstvene zaštite, NN, br. 18/18.

2. Zakon o liječništvu, NN, br. 121/03, 117/08.

3. Zakon o obveznim odnosima, NN, br. 35/05, 41/08, 125/11, 78/15, 29/18

4. Zakon o parničnom postupku, Službeni list SFRJ, br. 4/77, (...); NN, br. 53/91, (...) 89/14.

5. Zakon o zdravstvenoj zaštiti, NN, br. 150/08, 155/09, 71/10, 139/10, 22/11, 84/11, 154/11, $12 / 12,35 / 12,70 / 12,144 / 12,82 / 13,159 / 13,22 / 14,154 / 14,70 / 16,131 / 17$.

Sudska praksa

Francuska

1. Francuski kasacijski sud (Cour de Cassation), Cass civ 1re, od 04. studenog 1964.

Republika Austrija

1. Vrhovni sud Austrije, 90b79/07v. od 8. veljače 2008.

\section{Republika Hrvatska}

1. VSRH, Rev 1584/1998-2 od 04. veljače 1999.

2. VSRH, Rev-6/02-2 od 3. srpnja 2003.

3. VSRH, 1808/00-2, od 15. listopada 2003.

4. VSRH, Rev-540/03-2 od 17. prosinca 2003. 
5. VSRH, Rev 876/06-2 od 10.1.2007.

\section{Republika Slovenija}

1. Vrhovni sud Republike Slovenije, II Ips 712/2004 od 16.2.2006.

2. Vrhovni sud Republike Slovenije, II Ips 190/2008 od 3. travnja 2008.

\section{Savezna Republika Njemačka}

1. Savezni Vrhovni sud Njemačke (BGH), presuda od 16. svibnja 1972. VersR 1972.

2. Savezni vrhovni sud Njemačke, presuda od 5. ožujka 1985., Medizinrecht, br. 3/1986.

3. Vrhovni zemaljski sud u Düsseldorfu, presuda od 6. ožujka 2003., Versicherungsrecht, br. 30/2003.

Sjedinjene Američke Države

1. Brown v. Lewisham and North Southwark Health Authority MLC 0081 (CA: 1999), Medical negligence.

2. Presuda drugostupanjskog suda (suca G. Stevena Ageeja) od 21.04.2006.g. povodom žalbe na presudu Okružnog suda grada Suffolka u predmetu Lawrence J. Monahan v. Obici medical management services, inc., broj predmeta: 051592.

3. Sharpe v. Southend Health Authority MLC 0661 (2000), Medical negligence.

\section{Mrežne stranice}

1. Arlen, Jennifer, Economic Analysis of Medical Malpractice Liability and its Reform, New York University Public Law and Legal Theory Working Papers. Paper 398, 2013., <http:// citeseerx.ist.psu.edu/viewdoc/download?doi=10.1.1.828.1313\&rep=rep1\&type=pdf $>, 5$. ožujka 2019.

2. Lewis, Morgan Jr., Medical malpractice costs continue to climb, Medical Economics, 11. Jan. 2012, <https://www.medicaleconomics.com/articles/medical-malpractice-costscontinue-climb\%20 2 , 5. ožujka 2019. 


\section{Hrvoje Vojković*}

Summary

\section{CIVIL LIABILITY FOR BREACH OF MEDICAL STANDARD AND COMPLEMENTARY ECONOMIC EFFECTS}

The research has confirmed that the very possibility of achieving a tort claim in the case of tort liability on account of medical malpractice represents per se a systemic incentive for a continual process of professionalisation of the healthcare service, i.e., the legal order impacts the quality standard of healthcare in terms of preventing undesired consequences of unprofessional medical procedures. The typical modality of breaching a medical standard is medical malpractice which regardless of typological characteristics appears in genere in the physician's actions, contrary to the rules of the healthcare profession as well as its moral and ethical principles, as actions not conforming to standards in modern medical science, and which results in infringing on the patient's health or life, meaning a breach of the right of personality. In determining medical malpractice, the courts will consider through a prism the physician's actions in terms of medical treatment in concreto whereby the measure of behaviour is the normally careful physician in line with the average standard valid for physicians - the bonus pater familias standard. In that sense, Croatian positive law and the legal order ad comparandum, establish the fundamental obligations for physicians in the undertaking of medical treatment, and in particular stipulate the duty of acting with heightened care, all in line with the rules of the profession and customs - due professional care. Adherence to the mentioned standard minimises the risk of suboptimal treatment which is contrary to rules of the medical profession - contra legis artis, and whereby the legal, medical and economic components are preventively harmonised. Literal application of the negligence rule, i.e., the tort system and its associated rights and economic implications in ultima linea, leads to the situation where the possible tortfeasor (medical/healthcare institution) provides medical services under the regime of the optimal care standard given that the legal system views the standard of medical action as equal to the economic category of optimal patient care.

Keywords: civil liability of physicians; due care; breach of medical standard; medical malpractice; health economics.

* Hrvoje Vojković, Ph.D., Gras Savoye Croatia d.d., Willis Towers Watson group, hvojkovic@, gmail.com 


\section{ZIVILRECHTLICHE HAFTUNG FÜR DIE VERLETZUNG DES MEDIZINISCHEN STANDARDS UND DEREN ÖKONOMISCHE AUSWIRKUNGEN}

Der Beitrag analysiert das zivilrechtlicheAspekt der Verletzung des medizinischen Standards während der medizinischen Behandlung und weist auf unterschiedliche Erscheinungsformen des ärztlichen Behandlungsfehlers hin. Ungeachtet ihrer typologischen Charakteristiken erscheint die Verletzung des medizinischen Standards in genere beim Vorgehen des Arztes entgegen der Regeln des Gesundheitsberufs und dessen moralischen und ethischen Grundsätzen, beziehungsweise beim Vorgehen, welche mit den etablierten Standards der modernen medizinischen Wissenschaft nicht im Einklang stehen. Im Rahmen der durchgeführten Forschung wurde der Begriff des rechtlich relevanten medizinischen Standards aufgrund des imaginären Modells des ärztlichen Vorgehens im Rahmen einer konkreten medizinischen Behandlung bestimmt. Dabei zieht man als relevanten rechtlichen Standard den Standard des ordentlichen Kaufmannes und des guten Experten in Betracht, deren Beachtung das Risiko der suboptimalen Behandlung, welche den Regeln des medizinischen Berufs (contra legis artis) zuwiderläuft, minimisiert. Die Anwendung der Regeln der Sorgfaltspflicht, beziehungsweise das Schadenersatzrecht mit seinen rechtlichen und wirtschaftlichen Implikationen trägt letztendlich dazu bei, dass der eventuelle Schädiger (Arzt / Gesundheitseinrichtung) die medizinische Leistung im Regime des Standards der optimalen Fürsorge zu erbringen versucht, weil dem Rechtssystem nach der genannte Standard des medizinischen Vorgehens und die ökonomische Kategorie der optimalen Fürsorge für den Patienten gleich sind.

Schlïsselwörter: zivilrechtliche Haftung des Arztes; die Sorgfaltspflicht des Arztes; Sorgfalt eines ordentlichen Kaufmannes; Verletzung des Standards der medizinischen Behandlung; ärztlicher Fehler; Gesundheitsökonomie.

Riassunto

\section{LA RESPONSABILITÀ CIVILE PER LA VIOLAZIONE DELLO STANDARD SANITARIO E CONSEGUENTI EFFETTI ECONOMICI}

E' stata condotta una ricerca sugli aspetti civilistici della violazione degli standard in occasione della prestazione di servizio di trattamenti sanitari e si sono osservate differenti forme di errori medici. Le consuete violazioni degli standard 
sanitari sono rappresentate in genere dall'attività del medico che sia contraria alle regole della professione medica, ai suoi principi morali ed etici, ovvero quando le azioni siano in contrasto con gli standard accertati della scienza medica. Nell'ambito della ricerca viene accertato il concetto di standard medico giuridicamente rilevante sulla base dell'ipotetico modello comportamentale del medico nel contesto del trattamento sanitario in concreto, laddove come standard giuridicamente rilevante si consideri quello del buon imprenditore e del buon professionista; quello cioè nel rispetto del quale si minimizzano il rischio dell'azione contra legis artis. Il rispetto della regola dell'attenzione doverosa, ovvero il sistema risarcitorio con le sue implicazioni giuridiche ed economiche, in ultima linea comporta che il potenziale danneggiante (medico/ ente sanitario) cerchi di adempiere al servizio sanitario nel regime di standard di cura ottimale visto che il sistema giuridico equipara l'attività sanitaria alla categoria economica di cura ottimale del paziente.

Parole chiave: responsabilità civile del medico; attenzione doverosa del medico; attenzione del buon imprenditore; violazione degli standard del trattamento sanitario; errore medico; economia degli enti sanitari. 